\title{
Identification of non-canonical NF- $\kappa$ B signaling as a critical mediator of Smac mimetic-stimulated migration and invasion of glioblastoma cells
}

\author{
A Tchoghandjian ${ }^{1}$, C Jennewein ${ }^{1}$, I Eckhardt ${ }^{1}$, K Rajalingam² and S Fulda ${ }^{\star, 1}$
}

As inhibitor of apoptosis (IAP) proteins can regulate additional signaling pathways beyond apoptosis, we investigated the effect of the second mitochondrial activator of caspases (Smac) mimetic BV6, which antagonizes IAP proteins, on non-apoptotic functions in glioblastoma (GBM). Here, we identify non-canonical nuclear factor- $\kappa \mathrm{B}$ (NF- $\kappa \mathrm{B})$ signaling and a tumor necrosis factor- $\alpha(T N F \alpha) / T N F$ receptor 1 (TNFR1) autocrine/paracrine loop as critical mediators of BV6-stimulated migration and invasion of GBM cells. In addition to GBM cell lines, BV6 triggers cell elongation, migration and invasion in primary, patient-derived GBM cells at non-toxic concentrations, which do not affect cell viability or proliferation, and also increases infiltrative tumor growth in vivo underscoring the relevance of these findings. Molecular studies reveal that BV6 causes rapid degradation of cellular IAP proteins, accumulation of NIK, processing of p100 to p52, translocation of p52 into the nucleus, increased NF- $\kappa \mathrm{B}$ DNA binding and enhanced NF- $\kappa$ B transcriptional activity. Electrophoretic mobility shift assay supershift shows that the NF- $\kappa B$ DNA-binding subunits consist of p50, p52 and RelB further confirming the activation of the non-canonical NF- $\kappa$ B pathway. BV6-stimulated NF$\kappa$ B activation leads to elevated mRNA levels of TNF $\alpha$ and additional NF- $\kappa$ B target genes involved in migration (i.e., interleukin 8 , monocyte chemoattractant protein 1, CXC chemokine receptor 4) and invasion (i.e., matrix metalloproteinase-9). Importantly, inhibition of NF- $\kappa$ B by overexpression of dominant-negative $I \kappa B \alpha$ superrepressor prevents the BV6-stimulated cell elongation, migration and invasion. Similarly, specific inhibition of non-canonical NF- $\kappa$ B signaling by RNA interference-mediated silencing of NIK suppresses the BV6-induced cell elongation, migration and invasion as well as upregulation of NF- $\kappa$ B target genes. Intriguingly, pharmacological or genetic inhibition of the BV6-stimulated TNF $\alpha$ autocrine/paracrine loop by the TNF $\alpha$-blocking antibody Enbrel or by knockdown of TNFR1 abrogates BV6-induced cell elongation, migration and invasion. By demonstrating that the Smac mimetic BV6 at non-toxic concentrations promotes migration and invasion of GBM cells via non-canonical NF- $\kappa$ B signaling, our findings have important implications for the use of Smac mimetics as cancer therapeutics.

Cell Death and Disease (2013) 4, e564; doi:10.1038/cddis.2013.70; published online 28 March 2013

Subject Category: Cancer

\begin{abstract}
Although inhibitor of apoptosis (IAP) proteins were initially described to function as endogenous caspase inhibitors, ${ }^{1}$ X-linked IAP (XIAP) but not cellular IAP1 (cIAP1) and clAP2 possesses the critical residues for direct inactivation of caspases. ${ }^{2}$ In addition, IAP proteins exert additional functions besides inhibiting apoptosis, for example, regulation of cell motility, migration and invasion, although their role in this context has been controversially discussed. On one side, XIAP was reported to exert a pro-migratory function in endothelial cells, ${ }^{3}$ to be required for cell motility by regulating actin polymerization ${ }^{4}$ and to cooperate with survivin to foster cell motility and invasion. ${ }^{5}$ Also, clAP1 was shown to regulate cell migration in a CARD-dependent manner, as mutation of
\end{abstract}

its CARD domain increased cell migration. ${ }^{6}$ On the other side, downregulation of XIAP or clAPs either by siRNA-mediated knockdown or utilization of second mitochondrial activator of caspases (Smac) mimetic were recorded to promote cell migration via phosphorylation of C-RAF and activation of the MAPK signaling cascade. ${ }^{7}$ In addition, depletion of XIAP or clAP1 was shown to trigger Rac1 accumulation, thereby enhancing cell elongation and migration. ${ }^{8}$

Furthermore, IAP proteins are key regulators of canonical and non-canonical nuclear factor- $\kappa \mathrm{B}$ (NF- $\kappa \mathrm{B})$ pathways. ${ }^{1}$ In resting cells, canonical NF- $\kappa \mathrm{B}$ signaling is blocked by $I_{\kappa} \mathrm{B} \alpha$, which sequesters NF- $\kappa \mathrm{B}$ subunits in the cytosol. ${ }^{9}$ On tumor necrosis factor (TNF) receptor 1 (TNFR1) activation,

\footnotetext{
${ }^{1}$ Institute for Experimental Cancer Research in Pediatrics, Goethe University, Frankfurt, Germany and ${ }^{2}$ Emmy Noether Group of the DFG, Institute of Biochemistry II, Goethe University Medical School, Frankfurt, Germany

*Corresponding author: S Fulda, Institute for Experimental Cancer Research in Pediatrics, Goethe University, Komturstr. 3a, 60528 Frankfurt, Germany. Tel: + 4969 67866557; Fax: + 4969 6786659157; E-mail: simone.fulda@ kgu.de

Keywords: Smac; IAP proteins; NF- $\kappa$ B; glioblastoma

Abbreviations: CAM, chicken chorioallantoic membrane; CIAP, cellular inhibitor of apoptosis; CXCR4, CXC chemokine receptor 4; DMSO, dimethylsulfoxyde; EMSA, electrophoretic mobility shift assay; F-actin, filamentous actin; FITC, fluorescein; GBM, glioblastoma; IAP, inhibitor of apoptosis; IL-8, interleukin 8; I $\kappa$ B $\alpha$-SR, I $\kappa$ B $\alpha$ superrepressor; MCP-1, monocyte chemoattractant protein 1; MMPs, matrix metalloproteinases; MTT, 3-(4,5-dimethylthiazol-2-yl)-2,5-diphenyltetrazolium bromide; $\mathrm{NF}-\kappa \mathrm{B}$, nuclear factor $\kappa \mathrm{B}$; NIK, NF- $\kappa \mathrm{B}$-inducing kinase; uPA, urokinase-type plasminogen activator; Smac, second mitochondrial activator of caspases; TNF $\alpha$, tumor necrosis factor $\alpha$; TNFR1, tumor necrosis factor receptor 1; XIAP, X-linked inhibitor of apoptosis

Received 09.12.12; revised 21.12.12; accepted 02.1.13; Edited by G Raschellá.
} 
$\mathrm{I}_{\kappa} \mathrm{B} \alpha$ gets phosphorylated and degraded, leading to p65/p50 nuclear translocation and transcriptional activation of NF- $\kappa \mathrm{B}$ target genes. E3 ligase activity of clAP proteins promotes activation of canonical NF- $\kappa$ B signaling by adding K63-linked ubiquitin chains on RIP1 kinase. ${ }^{10,11}$ In the non-canonical $\mathrm{NF}-\kappa \mathrm{B}$ pathway, NF- $\kappa \mathrm{B}$-inducing kinase (NIK) is constitutively degraded via a cIAP/TRAF complex. ${ }^{12,13}$ Downregulation of cIAP proteins leads to NIK accumulation, processing of $p 100$ to $p 52$, nuclear translocation of $p 52$ and NF- $\kappa$ B activation. ${ }^{14,15}$ $\mathrm{NF}-\kappa \mathrm{B}$ can control migration and invasion via transcriptional activation of pro-migratory and pro-invasive genes like CXC chemokines, urokinase-type plasminogen activator (UPA) and matrix metalloproteinases (MMPs). ${ }^{16}$

Glioblastoma (GBM) is the most frequent malignant brain tumor with a very poor prognosis and its aggressiveness involves a highly migratory and invasive phenotype. ${ }^{17,18}$ Constitutively activated NF- $\kappa \mathrm{B}$ has been linked to its invasive behavior and degree of malignancy. ${ }^{19,20}$

Overexpression of IAP proteins correlates with poor prognosis and treatment resistance of cancers. ${ }^{4,21,22}$ Chromosomal amplification of 11q22. containing the loci of clAP1/2 often occurs in $\mathrm{GBM}^{23}$ and IAP proteins are overexpressed in GBM cell lines. ${ }^{24}$ During apoptosis, IAP proteins are antagonized by Smac that is released from the mitochondria. ${ }^{25,26}$ Similarly, small-molecule
Smac mimetics bind and neutralize IAP proteins. ${ }^{1}$ In this study, we investigated the role of the Smac mimetic BV6 in the regulation of migration and invasion using GBM as a model.

\section{Results}

BV6 at non-toxic concentration stimulates cell elongation of GBM cells. To investigate whether non-toxic concentrations of the Smac mimetic BV6 regulates additional pathways besides apoptosis in GBM cells, we initially determined its non-lethal concentrations. Concentrations of BV6 up to a $2.5 \mu \mathrm{M}$ had no effect on cell viability or caspase-3 activation (Figures $1 \mathrm{a}$ and $\mathrm{b}$ ). To control the biological activity of BV6 at these conditions we assessed IAP protein levels, because BV6 triggers autoubiquitination of IAP proteins. ${ }^{14}$ BV6 caused profound depletion of clAP1 protein in all three cell lines consistent with a previous report that clAP1 is especially susceptible to Smac mimetic-stimulated degradation. ${ }^{14,15,27}$ In addition, BV6-triggered degradation of XIAP and clAP2 in T98G and LN229 cells, whereas U87MG cells showed no changes in XIAP levels and little expression of clAP2 protein (Figure 1b). Therefore, we used $2.5 \mu \mathrm{M}$ BV6 for all subsequent experiments as a non-toxic concentration that causes depletion of clAP proteins.
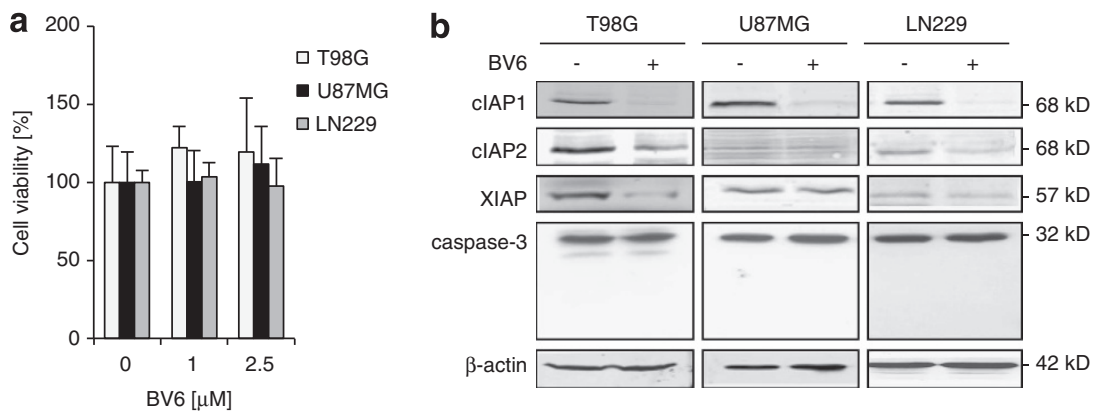

C
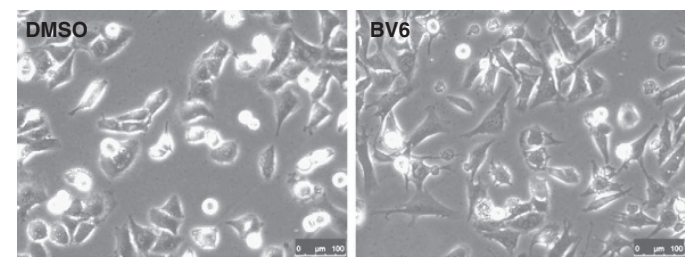

e
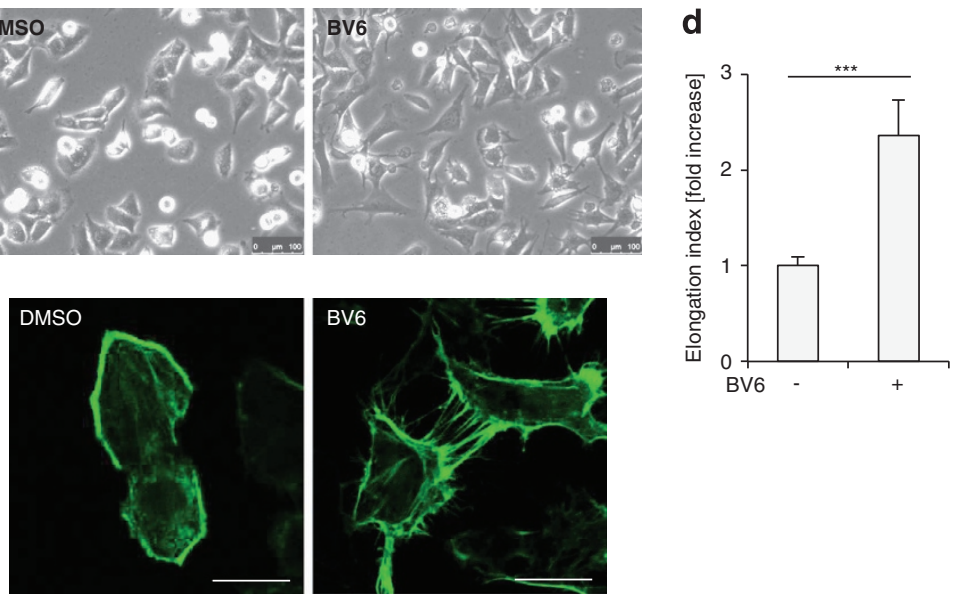

Figure 1 BV6 triggers cell elongation of GBM cells. (a) T98G, U87MG and LN229 GBM cells were treated for $24 \mathrm{~h}$ with indicated concentrations of BV6 or DMSO. Cell viability was measured by MTT assay and is expressed as the percentage of untreated controls. (b) T98G, U87MG and LN229 cells were treated for $24 \mathrm{~h}$ with $2.5 \mu \mathrm{M}$ BV6 or DMSO. Expression levels of cIAP1, cIAP2, XIAP and caspase-3 were analyzed by western blotting. Expression of $\beta$-actin served as loading control. (c and d) T98G cells were treated for $24 \mathrm{~h}$ with $2.5 \mu \mathrm{M}$ BV6 or DMSO. Cell morphology was analyzed by phase-contrast microscope; scale bar: $250 \mu \mathrm{m}$ (c). Cell elongation was quantified by measuring cell length and width and by calculating cell elongation index (length/width); fold increase in elongation index in the presence and absence of BV6 is shown (d). (e) T98G cells were treated for $24 \mathrm{~h}$ with $2.5 \mu \mathrm{M}$ BV6 or DMSO. Polymerization of F-actin was analyzed by phalloidin staining; scale bar: $20 \mu \mathrm{m}$. In (b, c and e), representative experiments of three independent experiments are shown. In (a and d), mean + S.D. of three independent experiments performed in triplicate are shown; ${ }^{* \star *} P<0.005$ 
To examine the effect of BV6 on non-apoptotic functions, we monitored the morphology of T98G cells by time-lapse microscopy. Interestingly, we observed that treatment with BV6-stimulated cell elongation with long cytoplasmic extensions compared with control cells with round shape and short cytoplasmic extensions (Figures 1c and d). To analyze actin polymerization as a typical feature of cell motility, we stained cells for filamentous actin (F-actin). Confocal microscopy showed that BV6-treated T98G cells exhibited long F-actinrich protrusions suggesting that BV6 stimulates changes in the cytoskeleton that are associated with cell motility (Figure 1e). Thus, BV6 at a sublethal concentration stimulates cell elongation of GBM cells.

BV6 at non-toxic concentration triggers migration and invasion of GBM cells and increases infiltrative growth of GBM in vivo. Based on our findings that BV6 stimulates morphological changes associated with increased cell motility, we next investigated whether BV6 has an effect on migration and invasion of GBM cells. Transwell migration assays showed that BV6 significantly increased migration of T98G, U87MG and LN229 cells (Figures 2a and b). In addition, BV6 significantly enhanced invasion of GBM cells (Figure 2c). To control that these BV6-stimulated changes in migration and invasion were not simply because of alterations in proliferation and/or cell cycle, we monitored these parameters in parallel. BV6 did not significantly change proliferation (Supplementary Figure S1A) or cell cycle distribution (Supplementary Figure S1B) at non-toxic conditions. Taken together, these data demonstrate that BV6 triggers migration and invasion of GBM cells.

Next, we asked whether BV6 also stimulates invasiveness of GBM cells in vivo. To address this question we used the chicken chorioallantoic membrane (CAM) model, an established preclinical tumor model. ${ }^{28,29}$ T98G cells were treated for $24 \mathrm{~h}$ with BV6 and were then seeded on the CAM of chicken embryos to allow tumor growth in vivo, which was assessed after 4 days. Importantly, pre-treatment of GBM cells with BV6 substantially increased the percentage of tumors with infiltrative growth in vivo compared with tumors derived from untreated GBM cells (Figure 2d). These data indicate that BV6 increases the infiltrative growth of GBM cells in vivo.

BV6 at non-toxic concentration activates the NF- $\kappa$ B pathway. Next, we aimed at identifying the underlying molecular mechanisms responsible for the BV6-stimulated cell elongation, migration and invasion. To this end, we examined the effect of BV6 on NF- $\kappa \mathrm{B}$ signaling, because BV6-mediated downregulation of IAP proteins has been reported to lead to NF- $\kappa \mathrm{B}$ activation. ${ }^{14}$ To monitor activation of the canonical NF- $\kappa \mathrm{B}$ pathway, we analyzed $\mathrm{I}_{\kappa} \mathrm{B} \alpha$ phosphorylation. $\mathrm{I}_{\kappa} \mathrm{B} \alpha$ was slightly phosphorylated after $2 \mathrm{~h}$ of BV6 stimulation accompanied by a slight decrease in $\mathrm{I}_{\kappa} \mathrm{B} \alpha$ protein levels (Figure $3 a$ ). As positive control for canonical $\mathrm{NF}-\kappa \mathrm{B}$ signaling, we used $\mathrm{TNF} \alpha$, which potently stimulated phosphorylation and degradation of $\mathrm{I} \kappa \mathrm{B} \alpha$ protein already after 5 min (Figure 3a). For monitoring non-canonical NF- $\kappa \mathrm{B}$ activation, we assessed accumulation of NIK protein and proteolytic processing of p100 to p52. BV6 rapidly caused accumulation of NIK and processing of p100 to p52 (Figure $3 \mathrm{~b}$ ). NIK accumulation and p100 processing to p52 was similarly detected in all three GBM cell lines (Figure 3c). To analyze that NF- $\kappa \mathrm{B}$ subunits translocate into the nucleus, we prepared cytosolic and nuclear extracts. BV6 stimulated nuclear translocation of p52 and p50 and slightly that of p65, whereas $\mathrm{TNF} \alpha$ primarily triggered p65 translocation (Figure 3d). DNA-binding assays showed that BV6 stimulated NF- $\kappa$ B DNA binding within the first hours of stimulation and over a prolonged time up to at least $24 \mathrm{~h}$ (Figure 3e). Interestingly, electrophoretic mobility shift assay (EMSA) supershift assay revealed that NF- $\kappa$ B DNA-binding complexes on stimulation with BV6 were mainly composed of p50, p52 and RelB subunits, because the addition of p50, p52 and/or RelB antibodies to nuclear extracts resulted in a supershift (for p50 antibody) or immunodepletion (for p52 and/or RelB antibodies) of DNA-binding complexes (Figure 3f). By comparison, p65 contributed to a minor extent to BV6-triggered NF- $\kappa$ B complex formation, indicating that BV6 mainly triggers non-canonical NF- $\kappa \mathrm{B}$ signaling. As prototypic stimulus of the canonical NF- $\kappa \mathrm{B}$ pathway, TNF $\alpha$-triggered increased DNA-binding of the p65 subunit and also of p50 (Figure 3f). To determine whether NF- $\kappa \mathrm{B}$ DNA-binding leads to transcriptional activation of $\mathrm{NF}-\kappa \mathrm{B}$ target genes we performed luciferase assay. BV6 significantly increased NF- $\kappa$ B transcriptional activity (Figure $3 g$ ). These experiments show that BV6 activates NF- $\kappa$ B signaling and in particular the non-canonical pathway in GBM cells resulting in enhanced $\mathrm{NF}-\kappa \mathrm{B}$ transcriptional activity.

$\mathrm{NF}-\kappa \mathrm{B}$ is required for $\mathrm{BV} 6$-induced cell elongation, migration and invasion. We next asked whether $\mathrm{NF}-\kappa \mathrm{B}$ activation is required for BV6-induced changes in cell shape and motility of GBM cells. To address this question, we overexpressed $I_{\kappa} \mathrm{B} \alpha$ superrepressor ( $\left.\mathrm{I}_{\kappa} \mathrm{B} \alpha-\mathrm{SR}\right)$ in T98G cells to inhibit NF- $\kappa B$ (Figure $4 \mathrm{a}$ ). Control experiments showed that $I_{\kappa} \mathrm{B} \alpha$ overexpression potently suppressed BV6- and TNF $\alpha$-stimulated NF- $\kappa$ B activation (Figure $4 b$ ) without altering cell viability on treatment with BV6 (Supplementary Figure $\mathrm{S} 1 \mathrm{C})$. Interestingly, inhibition of $\mathrm{NF}-\kappa \mathrm{B}$ by $\mathrm{I} \kappa \mathrm{B} \alpha-\mathrm{SR}$ resulted in increased NIK levels accompanied by profound downregulation of clAP2 expression (Figure 4c). As clAP2 is a prototypic $\mathrm{NF}-\kappa \mathrm{B}$ target gene and functions in complex with TRAF2/3 as E3 ligase for $\mathrm{NIK},{ }^{12,13}$ reduced clAP2 expression on $\mathrm{NF}-\kappa \mathrm{B}$ inhibition may account for stabilization of NIK protein. In addition, inhibition of $\mathrm{NF}-\kappa \mathrm{B}$ by $l_{\kappa} \mathrm{B} \alpha-\mathrm{SR}$ resulted in reduced expression of additional NF- $\kappa \mathrm{B}$ target genes, including $\mathrm{p} 100$, RelB and clAP1 (Figure 4c). ${ }^{30,31}$ As a side note, the short incubation time with BV6 to assess NIK accumulation (3h) may account for the fact that treatment with BV6 did not yet result in depletion of clAP2 protein in this experiment (Figure 4c) compared with clAP2 degradation in parental T98G cells on prolonged incubation with BV6 for $24 \mathrm{~h}$ (Figure 1b). Importantly, NF- $\kappa$ B inhibition prevented the BV6stimulated cell elongation compared with control cells (Figures $4 d$ and e). Also, the BV6-triggered increase in migration and invasion was blocked in I $k \mathrm{~B} \alpha$-SR-overexpressing cells compared with control cells (Figures $4 \mathrm{f}$ and $\mathrm{g}$ ). Together, this set of experiments demonstrates that $N F-\kappa B$ is required for BV6-stimulated cell elongation, migration and invasion. 
a

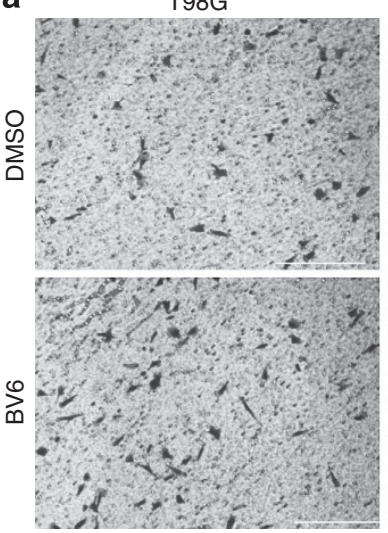

b

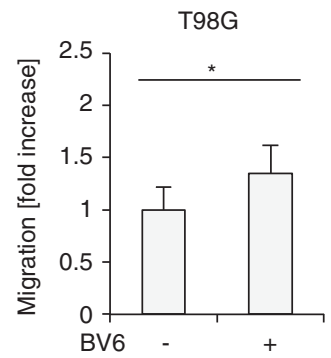

C

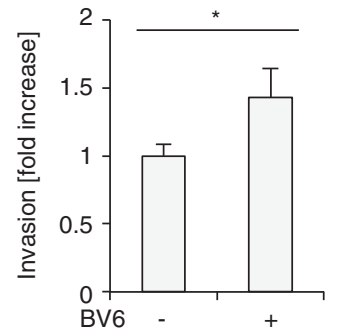

d
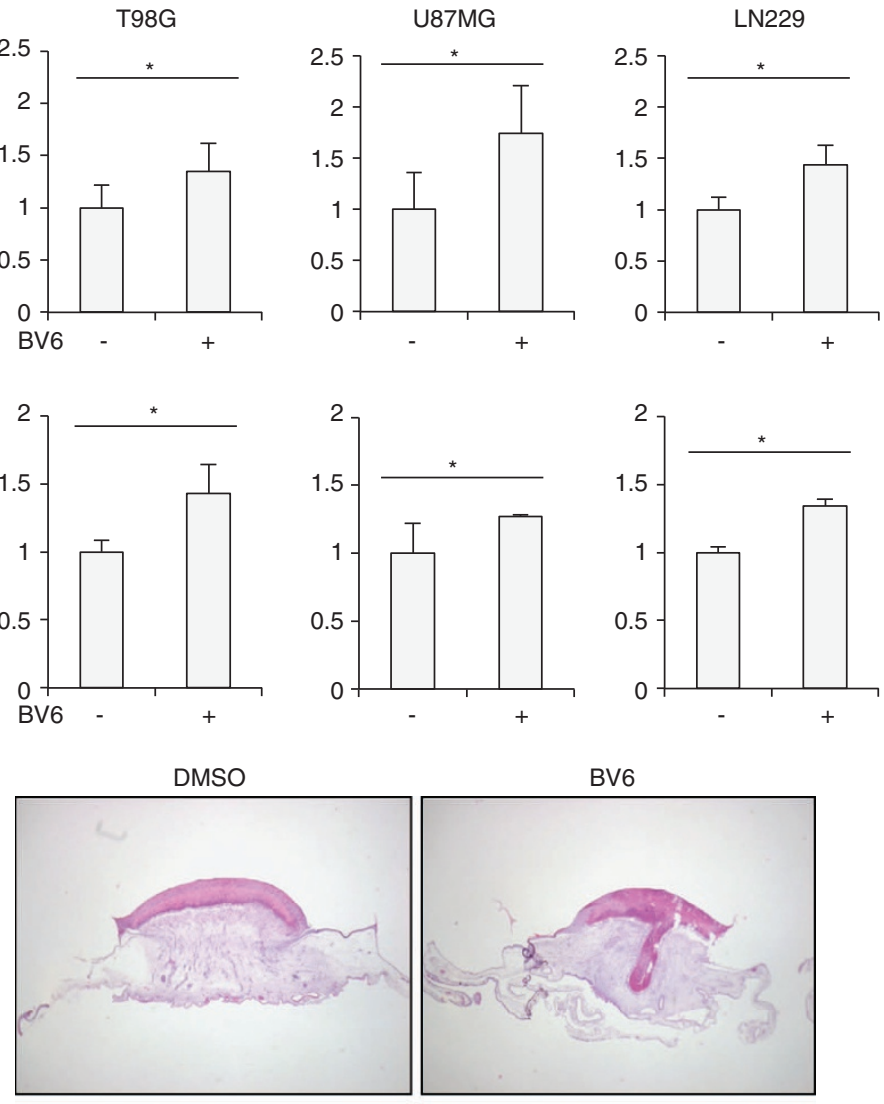

BV6
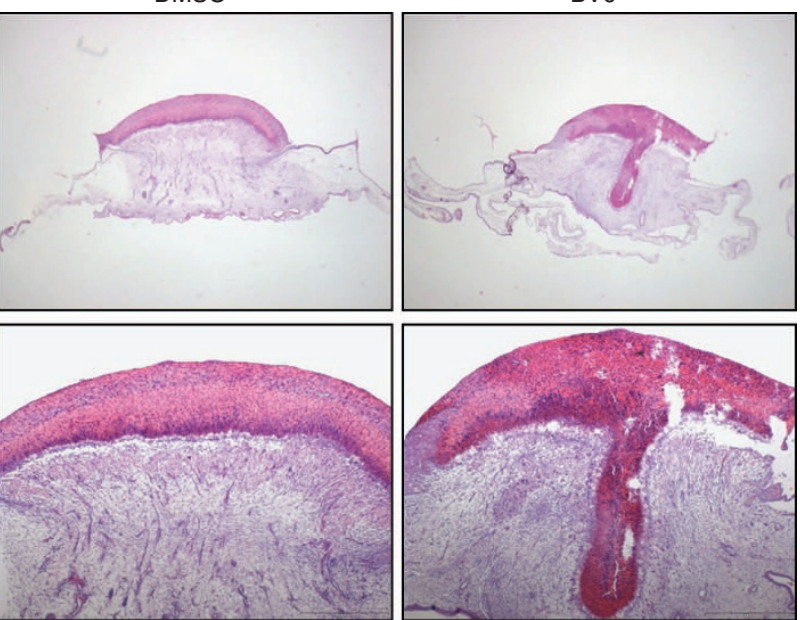
TNF $\alpha$ TNFR1 autocrine/paracrine signaling is required for BV6-induced cell elongation, migration and invasion. As TNF $\alpha$ is one of the key NF- $\kappa$ B target genes and has been described to regulate migration and invasion, ${ }^{16,32}$ we analyzed whether TNF $\alpha$ is upregulated on BV6 treatment. Quantitative RT-PCR analysis showed that within 3h BV6 rapidly stimulated an increase in TNF $\alpha$ mRNA levels (Figure 5a). Besides TNF $\alpha$, BV6 increased mRNA levels of additional NF- $\kappa \mathrm{B}$ target genes controlling cell migration, including the chemokines interleukin 8 (IL-8), monocyte chemoattractant protein 1 (MCP-1) and CXC chemokine receptor type 4 (CXCR4), or regulating migration such as the protease MMP9, whereas little or no changes in UPA and MMP2 mRNA levels were found (Figure 5b).

To test whether TNF $\alpha / T N F R 1$ signaling is required for the BV6-induced cell elongation, migration and invasion, we used a

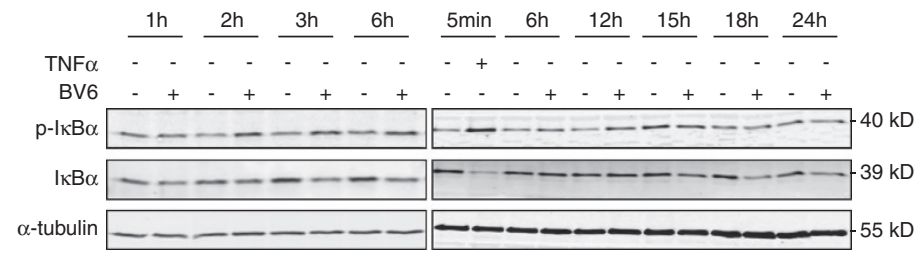

b

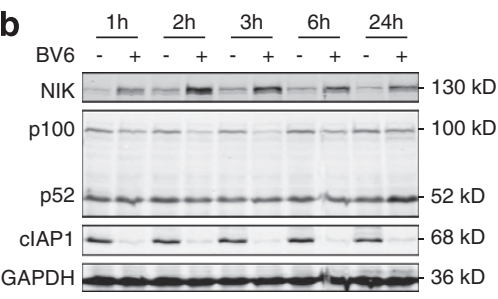

c

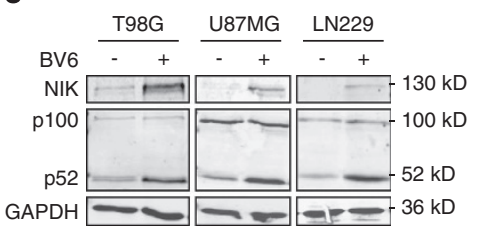

e
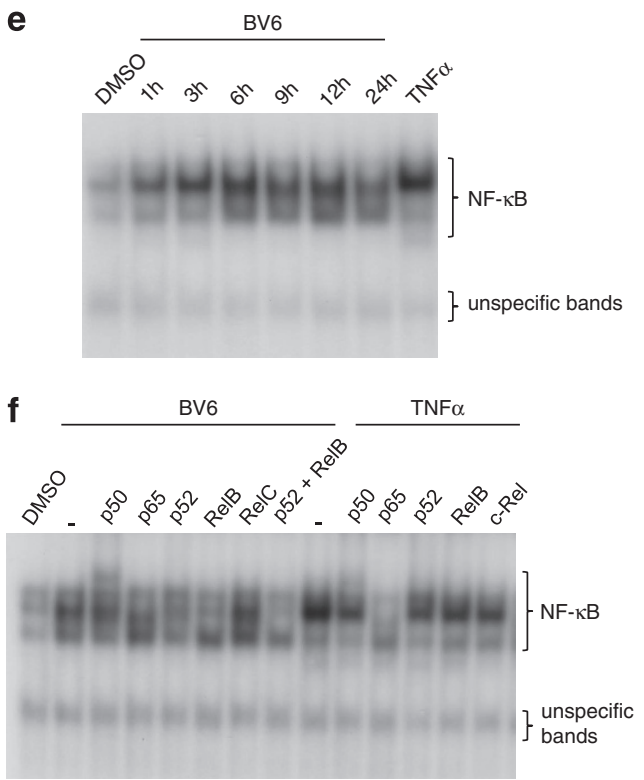

g

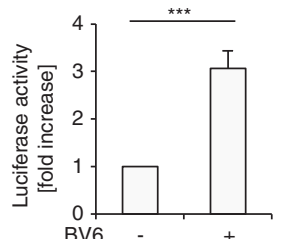

Figure 3 BV6 activates the non-canonical NF- $\kappa$ B pathway. (a) T98G cells were treated for indicated times with $2.5 \mu \mathrm{M} \mathrm{BV6}$ or DMSO; stimulation with $10 \mathrm{ng} / \mathrm{ml} \mathrm{TNF} \alpha$ for $5 \mathrm{~min}$ was used as positive control. Phosphorylation and expression of $\mathrm{I}_{\kappa} \mathrm{B} \alpha$ were analyzed by western blotting. Expression of $\alpha$-tubulin served as loading control. (b) T98G cells were treated for indicated times with $2.5 \mu \mathrm{M}$ BV6 or DMSO. Expression levels of NIK, p100, p52 and cIAP1 were analyzed by western blotting. Expression level of GAPDH served as loading control. (c) T98G, U87MG and LN229 cells were treated for $24 \mathrm{~h}$ with $2.5 \mu \mathrm{M} \mathrm{BV} 6$ or DMSO. Expression levels of NIK, p100 and p52 were analyzed by western blotting. Expression of GAPDH served as loading control. (d) T98G, U87MG and LN229 cells were treated for $24 \mathrm{~h}$ with $2.5 \mu \mathrm{m} \mathrm{BV6}$ or DMSO; stimulation with $10 \mathrm{ng} / \mathrm{ml}$ TNF $\alpha$ for $1 \mathrm{~h}$ was used as positive control. Expression levels of p100, p52, p50, phospho-p65 (p-p65) and p65 were analyzed in cytoplasmic (C) and nuclear (N) fractions by western blotting. $\alpha$-tubulin served as loading control for cytoplasmic fractions and lamin A/C for nuclear fractions. (e) T98G cells were treated for indicated times with $2.5 \mu \mathrm{M}$ BV6 or DMSO; stimulation with $10 \mathrm{ng} / \mathrm{ml} \mathrm{TNF} \alpha$ for $1 \mathrm{~h}$ was used as positive control. Nuclear extracts were analyzed for NF- $\kappa$ B DNA-binding activity by EMSA. (f) T98G cells were treated for $6 \mathrm{~h}$ with $2.5 \mu \mathrm{M} \mathrm{BV} 6$ or DMSO or with $10 \mathrm{ng} / \mathrm{ml} \mathrm{TNF} \alpha$ for $1 \mathrm{~h}$. Nuclear extracts were analyzed for the composition of NF- $\kappa$ B DNA-binding complexes by EMSA supershift using the indicated antibodies. (g) T98G cells were treated for $24 \mathrm{~h}$ with $2.5 \mu \mathrm{M} \mathrm{BV} 6$ or DMSO. NF- $\kappa$ B transcriptional activity was determined by luciferase assay and fold increase in luciferase activity is shown. Mean + S.D. of three independent experiments performed in triplicate are shown; ${ }^{* * \star} P<0.005$. In (a-f), representative experiments of three $(\mathbf{a}-\mathbf{e})$ or two $(\mathbf{f})$ independent experiments are shown

\footnotetext{
Figure 2 BV6 triggers migration and invasion of GBM cells. ( $(\mathbf{a}$ and $\mathbf{b})$ T98G, U87MG and LN229 cells were treated with $2.5 \mu$ M BV6 or DMSO and allowed to migrate for $24 \mathrm{~h}$ in a transwell migration chamber. Migrated cells were fixed, stained with crystal violet and pictures were taken by phase-contrast microscope (scale bar: $500 \mu \mathrm{m}$ ); a representative experiment of three independent experiments is shown (a). Migration was quantified by dissolution of crystal violet staining and determination of optical density; fold increase in migration is shown (b). (c) T98G, U87MG and LN229 cells were cultivated for $24 \mathrm{~h}$ in FITC-collagen containing $2.5 \mu \mathrm{M}$ BV6 or DMSO. Invasion was assessed by determining the amount of FITC released into the supernatant. Fold increase in invasion in the presence and absence of BV6 is shown. (d) T98G cells were treated for $24 \mathrm{~h}$ with $2.5 \mu \mathrm{M} \mathrm{BV6}$ or DMSO for in vivo invasion assay. After treatment, one million cells were seeded on the CAM of chicken embryos and allowed to grow for 4 days. Tumor formation (tumor $>0.5 \mathrm{~cm}^{3}$ ) and infiltrative growth (growth of tumor cells inside the CAM) were analyzed by hematoxylin eosin-stained paraffin sections of the CAM. Representative pictures from three independent experiments are shown $(n=30$ eggs). Lower magnification (upper pictures): $\times 3$; higher magnification (lower pictures): $\times 4$; scale bar: $500 \mu \mathrm{m}$. The number and percentage of tumor formation and infiltrative tumors are indicated. In $(\mathbf{b}$ and $\mathbf{c})$, mean + S.D. of three independent experiments performed in duplicate are shown; ${ }^{*} P<0.05$
} 
a

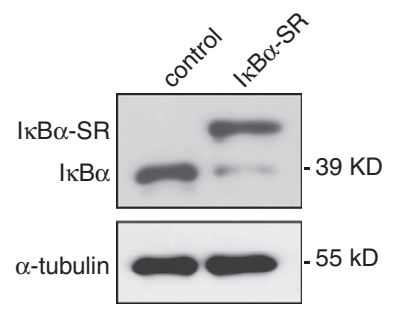

C

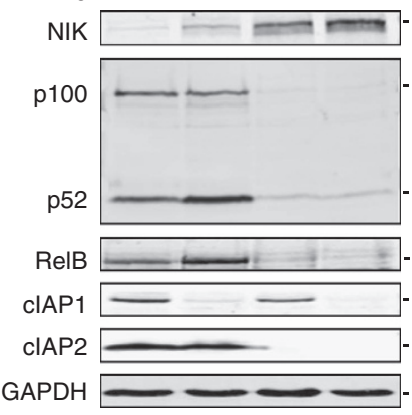

e

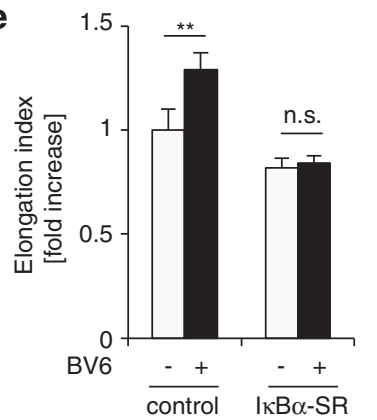

$36 \mathrm{kD}$

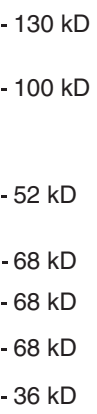

b

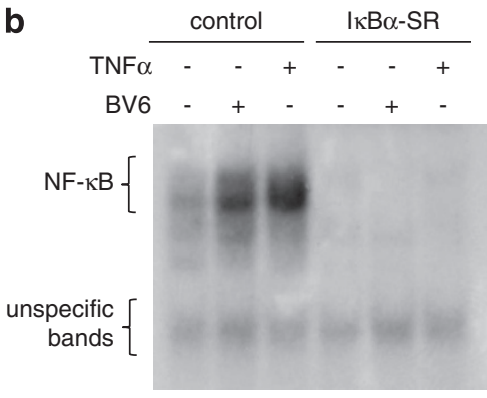

d
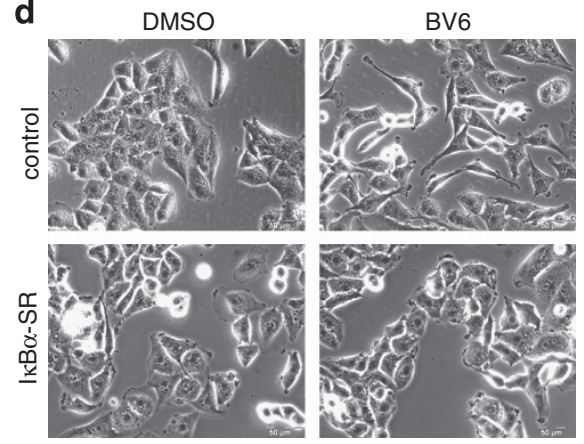
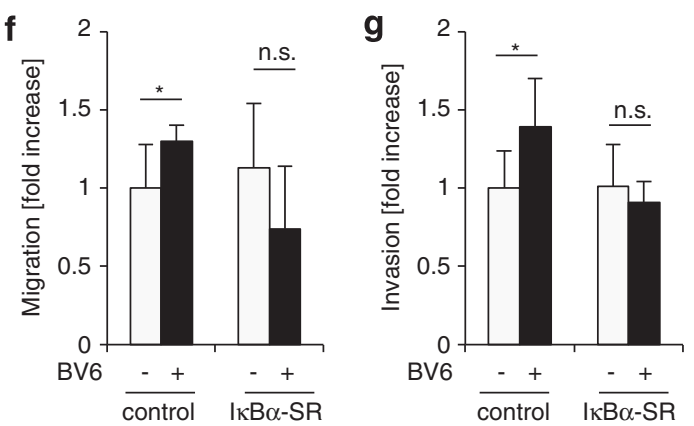

Figure $4 \mathrm{NF}-\kappa \mathrm{B}$ is required for BV6-induced cell elongation, migration and invasion. (a) T98G cells were transduced with $I_{\kappa} \mathrm{B} \alpha-\mathrm{SR}$ or vector control and analyzed for expression of $I_{\kappa} B \alpha$ by western blotting. $\alpha$-tubulin expression served as a loading control. (b) T98G cells stably expressing $I_{\kappa} B \alpha-S R$ or vector control were treated for $3 \mathrm{~h}$ with $2.5 \mu \mathrm{M} \mathrm{BV} 6$ or DMSO, stimulation with $10 \mathrm{ng} / \mathrm{ml}$ TNF $\alpha$ for $1 \mathrm{~h}$ was used as positive control. Nuclear extracts were analyzed by EMSA for NF- $\kappa \mathrm{B}$ DNA-binding activity. (c) T98G cells stably expressing $\mathrm{I}_{\kappa} \mathrm{B} \alpha$-SR or vector control were treated for $24 \mathrm{~h}$ with $2.5 \mu \mathrm{M}$ BV6 or DMSO. Expression levels of NIK, p100, p52, RelB, cIAP1 and cIAP2 were analyzed by western blotting. Expression of GAPDH served as loading control. (d and e) T98G cells stably expressing $\mathrm{l}_{\kappa} \mathrm{B} \alpha-\mathrm{SR}$ or vector control were treated for $24 \mathrm{~h}$ with $2.5 \mu \mathrm{M} \mathrm{BV} 6$ or DMSO. Cell morphology was analyzed by phase-contrast microscope; scale bar: $50 \mu \mathrm{m}$. A representative experiment of three experiments is shown (d). Cell elongation was quantified by measuring cell length and width and by calculating cell elongation index (length/width); fold increase in elongation index is shown (e). (f) T98G cells transduced with $\mathrm{l} \kappa \mathrm{B} \alpha$-SR or vector control were treated with $2.5 \mu \mathrm{M}$ BV6 or DMSO and allowed to migrate for $24 \mathrm{~h}$ in a transwell migration chamber. Migrated cells were fixed and stained with crystal violet. Migration was quantified by dissolution of crystal violet staining and determination of optical density. (g) T98G cells transduced with $1 \kappa B \alpha-S R$ or vector control were treated with $2.5 \mu \mathrm{M} \mathrm{BV6}$ or DMSO and allowed to invade for $24 \mathrm{~h}$ in a collagen-coated transwell migration chamber. Invasive cells were fixed and stained with crystal violet. Invasion was quantified by dissolution of the crystal violet staining and determination of optical density. In (a-d), a representative experiment of two (a-c) or three (d) independent experiments is shown. In $(\mathbf{e}-\mathbf{g})$, mean + S.D. of three independent experiments are shown; ${ }^{*} P<0.05 ;{ }^{\star} P<0.01 ; n . s$. not significant

the soluble TNF $\alpha$ antibody Enbrel as a pharmacological approach to abolish a putative TNF $\alpha$ autocrine/paracrine signaling loop. Control experiments showed that Enbrel neither alone nor in combination with BV6 was cytotoxic to T98G cells (Supplementary Figure S2A), whereas it potently blocked DNA fragmentation after co-treatment with BV6 and $\mathrm{TNF} \alpha$ that was used as a positive control for Enbrel (Supplementary Figure S2B). Interestingly, the addition of Enbrel inhibited the BV6-stimulated increase in cell elongation, migration and invasion, whereas Enbrel alone had no effect on these parameters (Figures $5 \mathrm{c}-\mathrm{e}$ ). In a second genetic approach to block TNF $\alpha /$ TNFR1 signaling, we knocked down TNFR1 by RNA interference (Figure 6a). Control experiments showed that TNFR1 knockdown did not affect sensitivity towards BV6, whereas it significantly reduced DNA fragmentation after co-treatment with BV6 and TNF $\alpha$ that was used as a positive control for TNFR1 knockdown (Supplementary Figures S2C, S2D). Importantly, TNFR1 knockdown prevented the BV6-induced cell elongation, migration and invasion, whereas BV6 significantly increased cell elongation, migration and invasion in nonsilencing control cells (Figures $6 b-d$ ). To investigate whether 
a

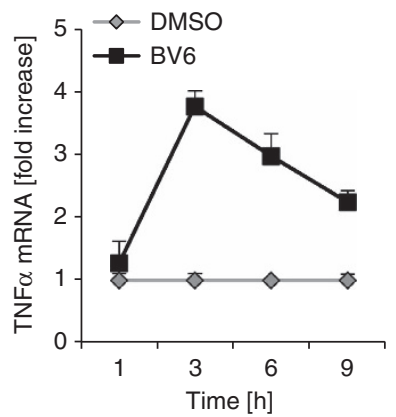

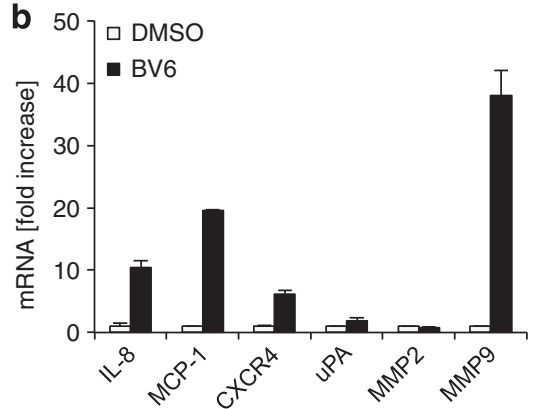
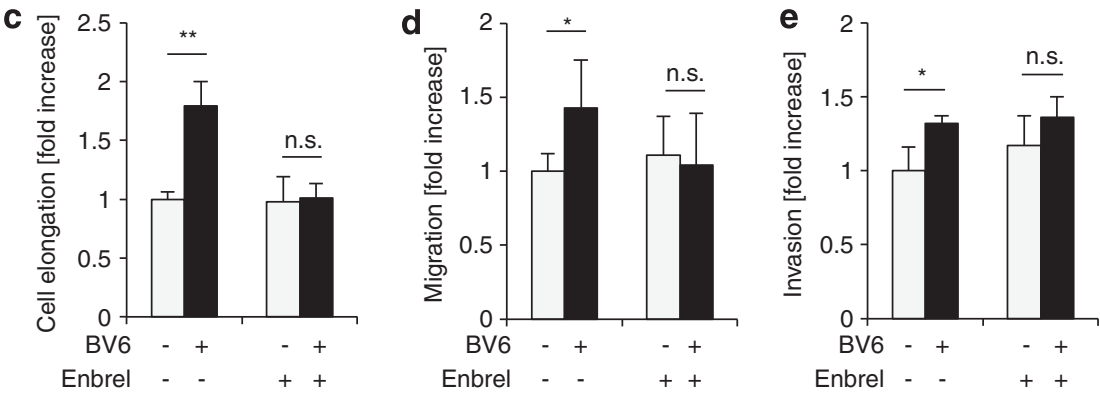

Figure 5 TNF $\alpha$ is required for BV6-induced cell elongation, migration and invasion. (a) T98G cells were treated for indicated times with $2.5 \mu \mathrm{M} \mathrm{BV6}$ or DMSO. TNF $\alpha$ mRNA levels were analyzed by quantitative RT-PCR and fold increase in TNF $\alpha$ mRNA levels is shown. Mean + S.D. values of two independent experiments are shown. (b) T98G cells were treated with $2.5 \mu \mathrm{M} \mathrm{BV} 6$ or DMSO. mRNA levels of indicated NF- $\kappa$ B target genes were analyzed by quantitative RT-PCR and are shown as fold increase for maximal induction (IL-8 and MCP-1 after $6 \mathrm{~h}, \mathrm{CXCR} 4$ after $9 \mathrm{~h}$, UPA and MMP9 after $24 \mathrm{~h}$ ). Mean + S.D. values of two independent experiments are shown. (c-e) T98G cells were treated for $24 \mathrm{~h}$ with $2.5 \mu \mathrm{M} \mathrm{BV} 6$ and/or $100 \mu \mathrm{g} / \mathrm{ml}$ Enbrel. Cell morphology was analyzed by phase-contrast microscope. Cell elongation was quantified by measuring cell length and width and by calculating cell elongation index (length/width); fold increase in elongation index is shown (c). Migrated cells were fixed and stained with crystal violet. Migration was quantified by dissolution of crystal violet staining and determination of optical density (d). Cells were allowed to invade in a collagen-coated transwell migration chamber; invasive cells were fixed, stained with crystal violet and optical density was measured (e). In (c-e) mean + S.D. values of three independent experiments performed in triplicate (c) and duplicate ( $\mathbf{d}$ and $\mathbf{e}$ ) are shown; ${ }^{\star} P<0.05 ;{ }^{\star \star} P<0.01 ;$ n.s. not significant
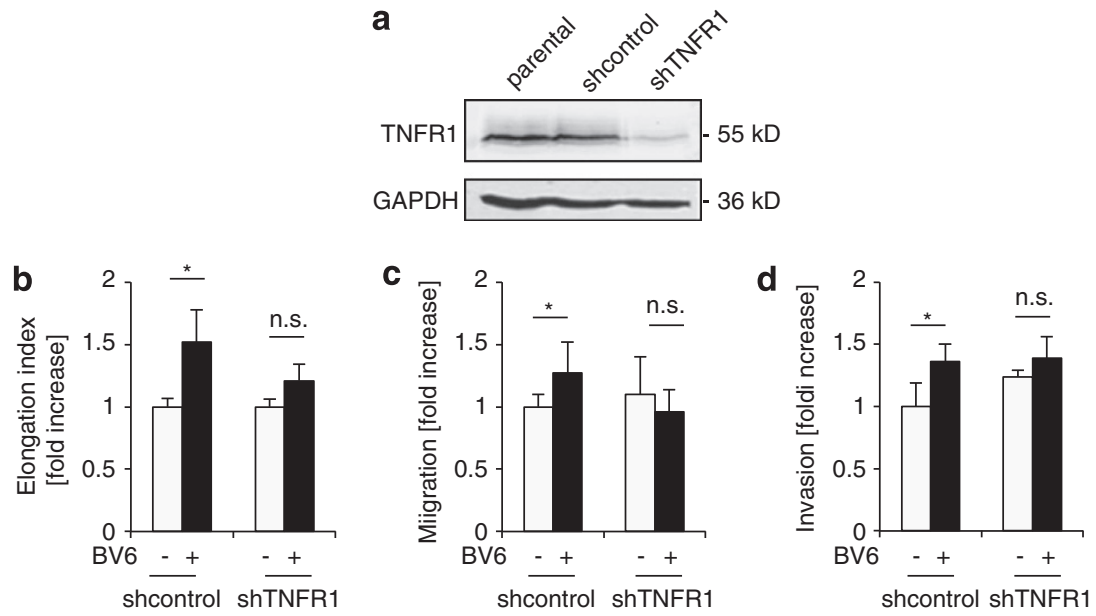

Figure 6 TNFR1 knockdown inhibits BV6-induced cell elongation, migration and invasion. (a) T98G cells were lentivirally transduced with shRNA against TNFR1 or vector control and knockdown of TNFR1 was assessed by western blotting. GAPDH expression served as loading control. (b-d) T98G cells transduced with shRNA against TNFR1 or control vector were treated for $24 \mathrm{~h}$ with $2.5 \mu \mathrm{M}$ BV6. Cell morphology was analyzed by phase-contrast microscope. Cell elongation was quantified by measuring cell length and width and by calculating cell elongation index (length/width); fold increase in elongation index is shown (b). Migrated cells were fixed and stained with crystal violet. Migration was quantified by dissolution of crystal violet staining and determination of optical density (c). Cells were allowed to invade in a collagen-coated transwell migration chamber; invasive cells were fixed, stained with crystal violet and optical density was measured (d). In (a), a representative experiment of two independent experiments is shown, in (b-d) mean + S.D. values of three independent experiments performed in triplicate (b) or duplicate (c and $\mathbf{d})$ are shown; ${ }^{*} P<0.05 ; n$.s. not significant

increased mRNA levels of IL-8, MCP-1 and MMP9 are also a consequence of $\mathrm{TNF} \alpha$ autocrine/paracrine signaling, we determined mRNA levels of these cytokine genes in the presence and absence of Enbrel. The addition of Enbrel reduces the BV6-triggered upregulation of IL-8, MCP-1 and MMP9 mRNA levels (Supplementary Figure S2E) indicating 
that $\mathrm{TNF} \alpha$ autocrine/paracrine signaling is involved in BV6induced increase in IL-8, MCP-1 and MMP9 expression. Together, this set of experiments demonstrates that BV6 increases the expression of $\mathrm{NF}-\kappa \mathrm{B}$ target genes including $\mathrm{TNF} \alpha$, which in turn engages a TNF $\alpha / T N F R 1$ autocrine/ paracrine signaling loop that is required for the BV6-induced cell elongation, migration, invasion and induction of $\mathrm{NF}-\kappa \mathrm{B}$ target genes.

NIK is required for BV6-induced cell elongation, migration and invasion. To further investigate the role of the non-canonical NF- $\kappa$ B pathway, we created T98G cells with knockdown of NIK (shNIK; Supplementary Figure S3A). Control experiments showed that NIK knockdown reduced BV6-stimulated NIK accumulation, p100 processing to p52 and NF- $\kappa$ B DNA-binding compared with non-silencing control cells (Figures $7 \mathrm{a}$ and b). By comparison, NIK silencing did not interfere with NF- $\kappa$ B binding on TNF $\alpha$ stimulation (Figure 7b), consistent with activation of the canonical NF- $\kappa$ B pathway by $\mathrm{TNF} \alpha$ (Figures $3 a$ and $\mathrm{f}$ ). Control experiments also showed that NIK knockdown did not alter the sensitivity toward BV6 compared with control cells (Supplementary Figure S3B). Importantly, NIK silencing prevented BV6-stimulated increase in cell a

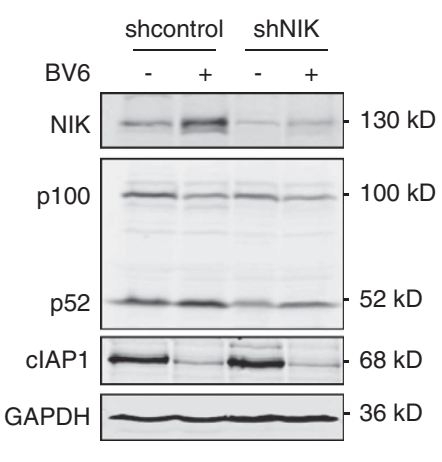

C
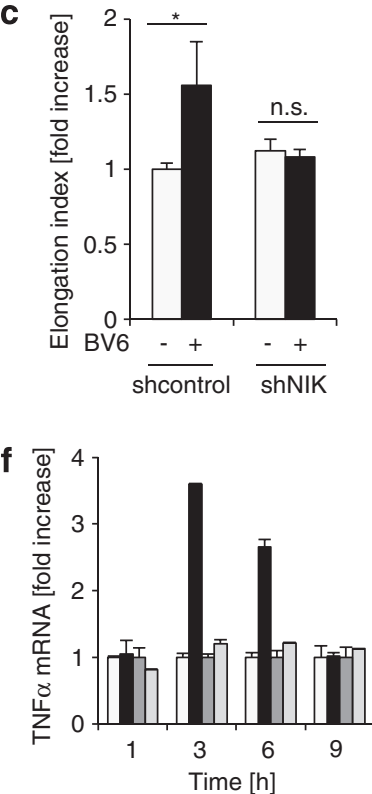
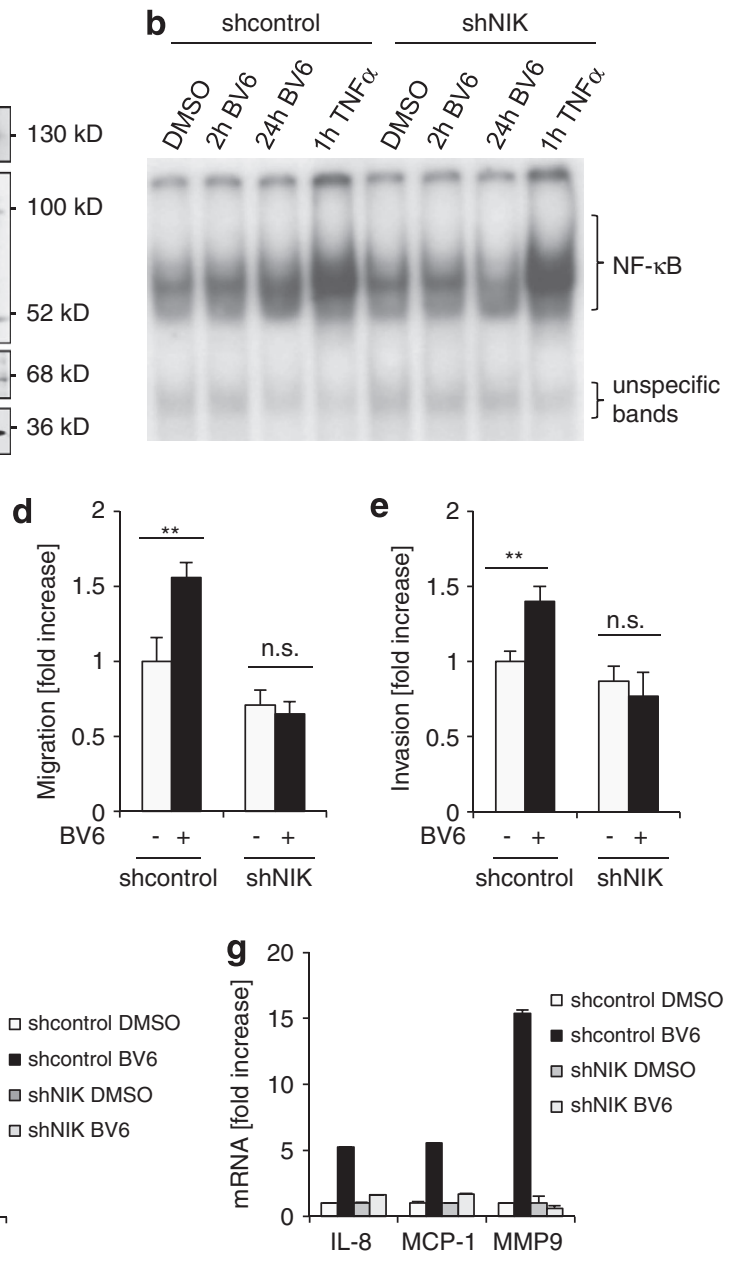

Figure 7 NIK is required for BV6-induced cell elongation, migration and invasion. (a) T98G cells transduced with shRNA against NIK or vector control were treated for $24 \mathrm{~h}$ with $2.5 \mu \mathrm{M}$ BV6. Expression levels of NIK, p100, p52 and cIAP1 were analyzed by western blotting. Expression of GAPDH served as loading control. (b) T98G cells transduced with shRNA against NIK (shNIK) or vector control were treated for 2 and $24 \mathrm{~h}$ with $2.5 \mu \mathrm{M} \mathrm{BV6}$, stimulation with $10 \mathrm{ng} / \mathrm{ml}$ TNF $\alpha$ for $1 \mathrm{~h}$ was used as positive control. Nuclear extracts were prepared and analyzed for NF- $\kappa$ B DNA-binding activity by EMSA. NIK knockdown slightly reduced BV6-stimulated NF- $\kappa$ B DNA-binding after treatment with BV6 for $24 \mathrm{~h}$ compared with non-silencing control cells. (c-e) T98G cells transduced with shRNA against NIK or vector control were treated for $24 \mathrm{~h}$ with $2.5 \mu \mathrm{M}$ BV6. Cell morphology was analyzed by phase-contrast microscope. Cell elongation was quantified by measuring cell length and width and by calculating cell elongation index (length/ width); fold increase in elongation index is shown (c). Migrated cells were fixed and stained with crystal violet. Migration was quantified by dissolution of crystal violet staining and determination of optical density (d). Cells were allowed to invade in a collagen-coated transwell migration chamber; invasive cells were fixed, stained with crystal violet and optical density was measured (e). (f) T98G cells transduced with shRNA against NIK or vector control were treated for indicated times with $2.5 \mu \mathrm{M} \mathrm{BV6}$. TNF $\alpha$ mRNA levels were analyzed by quantitative RT-PCR and fold increase in TNF $\alpha$ mRNA levels is shown. $(\mathbf{g})$ T98G cells transduced with shRNA against NIK or vector were treated with $2.5 \mu \mathrm{M}$ BV6. mRNA levels of indicated NF- $\kappa$ B target genes were analyzed by quantitative RT-PCR and are shown as fold increase for maximal induction (IL-8 and MCP-1 after $6 \mathrm{~h}$, and MMP9 after $24 \mathrm{~h}$ ). In (a and b), representative experiments from two (a) or three (b) experiments are shown. In (c-g), mean + S.D. values of three (c-e) or two (f and $\mathbf{g}$ ) independent experiments performed in triplicate $(\mathbf{c}, \mathbf{f}$ and $\mathbf{g})$ and duplicate $(\mathbf{d}$ and $\mathbf{e})$ are shown; ${ }^{*} P<0.05 ;{ }^{* *} P<0.01 ;$ n.s. not significant 
elongation, migration and invasion compared with control cells (Figures 7c-e).

As our results show that $\mathrm{TNF} \alpha$ is upregulated on BV6 treatment (Figure 6a) and required for BV6-stimulated cell elongation, migration and invasion (Figures $6 b-d$ ), we next analyzed whether TNF $\alpha$ levels increase in a NIK-dependent manner. Interestingly, BV6-stimulated upregulation of TNF $\alpha$ was strongly reduced in NIK knockdown cells compared with non-silencing control cells (Figure 7f). In addition, the BV6mediated upregulation of IL-8, MCP-1 and MMP9 was profoundly suppressed in NIK knockdown cells (Figure 7g). These experiments indicate that NIK is required for BV6induced cell elongation, migration, invasion and induction of $\mathrm{NF}-\kappa \mathrm{B}$ target genes.
BV6 triggers cell elongation, migration and invasion in primary GBM cells. To test the potential clinical relevance of our findings, we extended our experiments to primary GBM cells derived from patients' specimens. BV6 at low micromolar concentrations caused profound depletion of clAP1 without altering cell viability or triggering caspase-3 cleavage, whereas BV6 had no or minor effects on expression levels of clAP2 and XIAP (Figures $8 a$ and b). Also, BV6 induced accumulation of NIK protein and p100 processing to $\mathrm{p} 52$, indicating that it stimulates non-canonical $\mathrm{NF}-\kappa \mathrm{B}$ signaling in primary GBM cells (Figure $8 \mathrm{c}$ ). Importantly, BV6 significantly increased cell elongation, migration and invasion of both GBM1 and GBM2 cells (Figures 8d-f). These findings demonstrate that BV6 at non-toxic
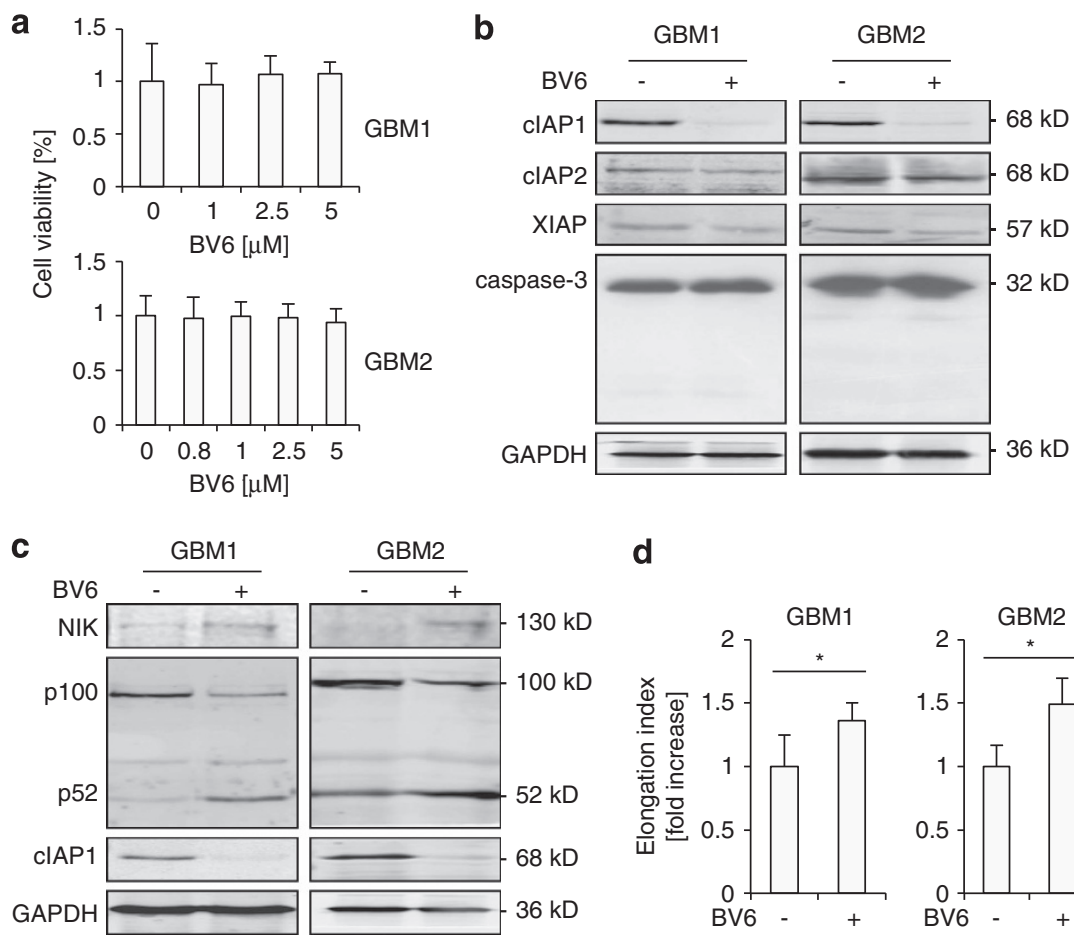

e
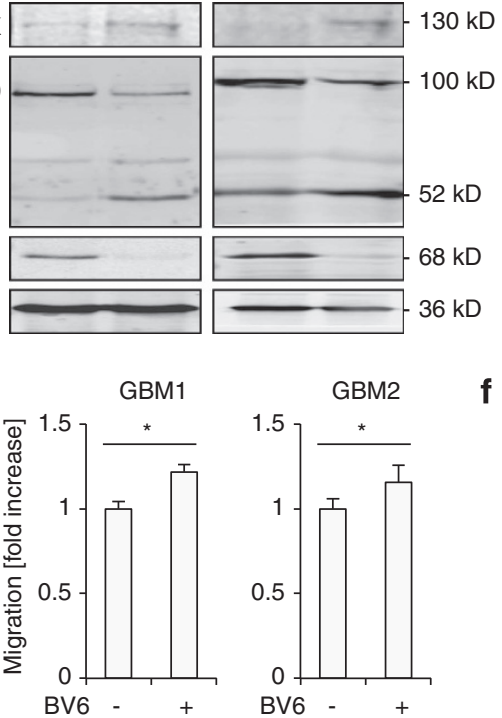

d
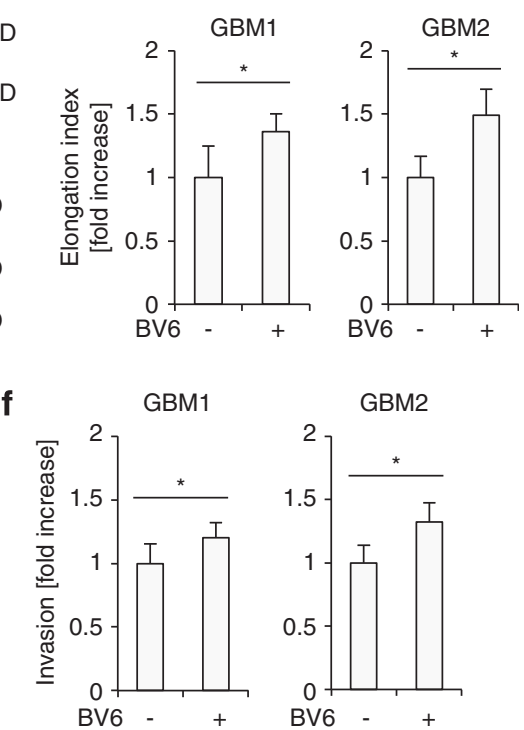

Figure 8 BV6 triggers cell elongation, migration and invasion of primary GBM cells. (a) Primary GBM cells derived from two distinct specimens (GBM1, GBM2) were treated for $24 \mathrm{~h}$ with indicated concentrations of BV6. Cell viability was measured by MTT assay and is expressed as the percentage of untreated controls. (b) Primary GBM cells were treated with BV6 (GBM1: $1 \mu \mathrm{M}$ BV6, GBM2: $0.8 \mu \mathrm{M} \mathrm{BV6}$ ) for $24 \mathrm{~h}$. Expression levels of clAP1, clAP2, XIAP and caspase-3 were analyzed by western blotting. Expression level of GAPDH served as loading control. (c) Primary GBM cells were treated with BV6 (GBM1: $1 \mu \mathrm{M}$ BV6, GBM2: $0.8 \mu \mathrm{M}$ BV6) for 24 h. Expression levels of p100, p52 and clAP1 were analyzed by western blotting. Expression level of GAPDH served as a loading control. (d-f) Primary GBM cells were treated with BV6 (GBM1: $1 \mu$ M BV6, GBM2: $0.8 \mu \mathrm{M}$ BV6) for $24 \mathrm{~h}$. Cell morphology was analyzed by phase-contrast microscope. Cell elongation was quantified by measuring cell length and width and by calculating cell elongation index (length/width); fold increase in elongation index is shown (d). Migrated cells were fixed and stained with crystal violet. Migration was quantified by dissolution of crystal violet staining and determination of optical density (e). Cells were allowed to invade in a collagen-coated transwell migration chamber; invasive cells were fixed, stained with crystal violet and optical density was measured (f). In (a, d-f), mean + S.D. values of three independent experiments performed in triplicate (a and $\mathbf{d}$ ) and in duplicate (e and $\mathbf{f}$ ) are shown; ${ }^{*} P<0.05$. In ( $\mathbf{b}$ and $\mathbf{c}$ ), representative experiments from two experiments are shown 
concentrations activates the non-canonical NF- $\kappa$ B pathway and triggers cell elongation, migration and invasion in primary GBM cells.

\section{Discussion}

We previously reported that small-molecule IAP antagonists such as Smac mimetic act in concert with cytotoxic strategies including chemotherapeutics, TRAIL or irradiations to induce apoptosis in GBM cells. ${ }^{33-36}$ Here, we report that the Smac mimetic BV6 as single agent at non-toxic concentrations exerts non-apoptotic functions in GBM cells: BV6 promotes cell elongation, migration and invasion of GBM cells by activating non-canonical NF- $\kappa \mathrm{B}$ signaling and a TNF $\alpha / T N F R 1$ autocrine/paracrine loop. This conclusion is supported by several independent pieces of evidence. First, treatment of GBM cells with BV6 results in predominant activation of the non-canonical NF- $\kappa$ B pathway as demonstrated by accumulation of NIK protein, proteolytic processing of $p 100$ to $p 52$, translocation of p52 from the cytosol into the nucleus, binding of the NF- $\kappa \mathrm{B}$ subunits p52, p50 and RelB to the DNA, transcriptional activation of NF- $\kappa \mathrm{B}$ and increased mRNA expression of NF- $\kappa$ B target genes including $\mathrm{TNF} \alpha$. By comparison, non-toxic concentrations of BV6 only slightly stimulate the canonical NF- $\kappa$ B pathway in GBM cells. Second, overexpression of $\mathrm{I} \kappa \mathrm{B} \alpha$-SR blocks activation of the non-canonical NF- $\kappa \mathrm{B}$ pathway and suppresses BV6-stimulated cell elongation, migration and invasion. Decreased expression levels of key components of the non-canonical NF- $\kappa$ B pathway such as p100 and RelB, which are $\mathrm{NF}-\kappa \mathrm{B}$ target genes, ${ }^{30,31}$ may contribute to inhibition of non-canonical NF- $\kappa \mathrm{B}$ signaling in $\mathrm{I} \kappa \mathrm{B} \alpha$-SR-overexpressing cells. Third, specific inhibition of the non-canonical NF- $\kappa$ B pathway by RNAi-mediated knockdown of NIK inhibits the BV6-induced cell elongation, migration and invasion as well as upregulation of $\mathrm{NF}-\kappa \mathrm{B}$ target genes such as TNF $\alpha$. Fourth, inhibition of the TNF $\alpha / T N F R 1$ autocrine/paracrine loop either by a pharmacological approach using the TNF $\alpha$-blocking antibody Enbrel or by a genetic strategy via RNAi-mediated silencing of TNFR1 suppresses cell elongation, migration and invasion on exposure to BV6. Together, these data underscore the critical role of non-canonical NF- $\kappa$ B signaling for BV6-stimulated cell elongation, migration and invasion.

The novelty of our study resides in the identification of the non-canonical NF- $\kappa$ B pathway as a critical mediator of BV6triggered cell elongation, migration and invasion of GBM cells. By monitoring activation of both the non-canonical and the canonical NF- $\kappa$ B pathway at different levels of the signaling cascade, we demonstrate that non-toxic concentrations of BV6 predominately stimulate non-canonical NF- $\kappa$ B signaling. This identification of non-canonical NF- $\kappa$ B signaling as a key mediator of the non-apoptotic functions of BV6 in the control of migration and invasion is particularly interesting in comparison with previous studies reporting that non-canonical NF- $\kappa \mathrm{B}$ signaling is required for Smac mimetic-triggered cytotoxicity. This indicates that the non-canonical NF- $\kappa \mathrm{B}$ pathway is involved in the regulation of both non-apoptotic and apoptotic processes on treatment with Smac mimetic in a contextdependent manner. Of note, in this study we used non-toxic concentrations of BV6 that cause depletion of clAP proteins and activation of the non-canonical NF- $\kappa$ B pathway but do not affect cell viability or proliferation. Thus, Smac mimetic may differentially engage non-apoptotic and apoptotic pathways in a concentration-dependent manner. The slight activation of the canonical NF- $\kappa \mathrm{B}$ pathway in our model may occur via a crosstalk with the non-canonical NF- $\kappa \mathrm{B}$ pathway, because NIK has been described to also interact and phosphorylate $\mathrm{IKK} \beta$, although IKK $\alpha$ is known as a preferential substrate for NIK. ${ }^{37,38}$ Although the impact of the canonical NF- $\kappa$ B pathway on migration and invasion has been extensively studied, ${ }^{16}$ there are only a few reports on the role of non-canonical $\mathrm{NF}-\kappa \mathrm{B}$ signaling in this context. In a murine system, IKK $\alpha^{-1-}$ or $\mathrm{p} 52^{-I-}$ macrophages or mouse embryo fibroblasts were demonstrated to fail to migrate toward the chemoattractant HMGB1, as they were unable to maintain the production of CXCL12/SDF1. ${ }^{39,40}$ Further, NIK was reported to be necessary for osteopontin-stimulated secretion of UPA, UPAdependent activation of pro-MMP-9 as well as cell migration and invasion. ${ }^{41}$

Another important finding of our study consists in the identification of a TNF $\alpha / T N F R 1$ autocrine/paracrine, nonapoptotic loop as critical mediator of BV6-stimulated migration and invasion, because all these effects are suppressed by the TNF $\alpha$-blocking antibody Enbrel and in TNFR1 knockdown cells. Of note, TNF $\alpha$ TNFR1 autocrine/ paracrine signaling has been implicated to mediate apoptosis of Smac mimetic at lethal concentrations. ${ }^{14,15}$ Thus, Smac mimetic may differentially engage non-apoptotic and apoptotic TNF $\alpha$ /TNFR1-mediated events in a context-dependent manner. TNF $\alpha / T N F R 1-$ stimulated signaling may contribute to non-canonical NF- $\kappa \mathrm{B}$ activation during BV6-stimulated migration and invasion. In RIP1-deficient cells, TNFR1 crosslinking was shown to engage the non-canonical NF- $\kappa \mathrm{B}$ pathway via TRAF2 downregulation. ${ }^{42,43}$ However, we found no evidence that TRAF2 expression decreases on BV6 stimulation (data not shown). Thus, further studies are required to explore whether $\mathrm{TNF} \alpha / \mathrm{TNFR} 1$ signaling is linked to non-canonical NF- $\kappa$ B pathway in our model.

The role of IAP proteins in cell migration has been controversially discussed, as some studies reported that IAP proteins promote motility and migration, ${ }^{3,5,6}$ whereas others - similar to our findings - demonstrated that migration is enhanced on depletion of IAP proteins. ${ }^{7,8}$ How can these controversies be reconciled? It is interesting to note that these studies differ with respect to whether or not NF- $\kappa$ B is activated and which NF- $\kappa$ B pathway is predominantly engaged on depletion of IAP proteins. Although we found that BV6 primarily stimulates the non-canonical NF- $\kappa \mathrm{B}$ pathway, Mehrotra et al. ${ }^{5}$ reported that XIAP and survivin act together to activate canonical NF- $\kappa \mathrm{B}$ signaling, whereas in another study Smac mimetic was shown to exert no effect on NF- $\kappa$ B transcriptional activity. ${ }^{6}$ The differences may also be explained by the balance in proliferation and cell death controlled by IAP proteins. As IAP proteins are key repressors of apoptosis, a decrease in their expression levels might promote cell death. This underscores the relevance of taking into consideration whether or not depletion of IAP proteins affects the rate of proliferation and/or cell death, as such effects may also have an impact on migration and invasion. 
Although we showed that non-toxic concentrations of BV6 do not alter proliferation, cell cycle progression or cell death, loss of clAP1/2 was previously reported to reduce the proliferation rate. ${ }^{6}$ Furthermore, the approach to antagonize IAP proteins in cancer cells, that is, via genetic manipulation of by pharmacological means, may affect the functional outcome. Also, the cellular context including differences in cell types (e.g., cancer versus non-malignant cells, mammalian versus murine models) may have an influence on the phenotype that is observed on depletion of IAP proteins. Moreover, the relative expression levels of distinct IAP proteins within the cells and the spectrum of IAP proteins that are neutralized by various Smac mimetics could encounter for differences in cellular responses.

Pharmacological antagonists of IAP proteins such as Smac mimetics are currently under evaluation in early clinical trials, thus highlighting the significance of studies to elucidate the impact of Smac mimetic on non-apoptotic as well as apoptotic functions. The potential clinical relevance of our findings is underlined by parallel experiments in primary GBM cells derived from patient-derived tumor specimens, which similarly demonstrate that BV6 at a non-lethal concentration activates non-canonical NF- $\kappa \mathrm{B}$ signaling and promotes cell elongation, migration and invasion. In addition, the BV6-stimulated increase in the invasiveness of GBM cells is reproduced in an in vivo model.

In summary, we identify non-canonical NF- $\kappa$ B signaling as an important mediator of BV6-stimulated migration and invasion of GBM cells. These findings have important implications for the application of Smac mimetics as cancer therapeutics.

\section{Materials and Methods}

Cell culture and chemicals. Human GBM cell lines T98G, U87MG and LN229 were obtained from ATCC (Manassas, VA, USA) and grown in DMEM medium (Invitrogen, Karlsruhe, Germany) supplemented with 1\% penicillin/streptomycin, $1 \%$ sodium pyruvate (both from Invitrogen) and 10\% fetal calf serum (Invitrogen). The bivalent Smac mimetic BV6 (ref. 14) was kindly provided by Genentech (South San Francisco, CA, USA), recombinant human TNF $\alpha$ was purchased from Biochrom (Berlin, Germany), MG132 from Enzo Life Sciences (Lörrach, Germany). Enbrel was kindly provided by Pfizer (Berlin, Germany). All chemicals were obtained from Sigma (Deisenhofen, Germany) unless indicated otherwise.

Transduction. Overexpression of the dominant-negative $\mid \kappa \mathrm{B} \alpha-\mathrm{SR}$ was performed by retroviral transduction using $I_{\kappa} \mathrm{B} \alpha(\mathrm{S} 32 ; 36 \mathrm{~A})$ and the pCFG5IEGZ retroviral vector system as previously described. ${ }^{44}$ Knockdown of NIK and TNFR1 was performed by lentiviral shRNA vectors as previously described. ${ }^{45}$ Shortly, HEK293T cells were transfected with $7.5 \mu \mathrm{g}$ pGIPZ-shRNAmir vector, using calcium phosphate transfection. All pGIPZ-shRNAmir-vectors were purchased from Thermo Fisher Scientific (Dreieich, Germany) (non-silencing control (NS): RHS4346, shNIK shRNA: RHS4430-99889385, shTNFR1 shRNA: RHS4430-101168495). Virus-containing supernatant was collected, filtered and used for spin transduction at $30^{\circ} \mathrm{C}$ in the presence of $8 \mu \mathrm{g} / \mathrm{ml}$ polybrene. Transduced cells were selected with $1 \mu \mathrm{g} / \mathrm{ml}$ puromycin (Sigma).

Determination of cell viability. Cell viability was assessed by 3-(4,5dimethylthiazol-2-yl)-2,5-diphenyltetrazolium bromide (MTT) assay according to the manufacturer's instructions (Roche Diagnostics, Mannheim, Germany).

Determination of cell elongation. Cells were seeded in 12-well plates 1 day before stimulation. Directly after stimulation with $\mathrm{BV} 6$, live cell imaging was performed at $37^{\circ} \mathrm{C}$ under $5 \% \mathrm{CO}_{2}$ for $24 \mathrm{~h}$ using Leica DMI6000B microscope (Leica Microsystems, Wetzlar, Germany). Images were taken each $15 \mathrm{~min}$ and processed using Leica application suite. Three independent experiments were recorded. Three pictures of each condition of the $24 \mathrm{~h}$ time point were selected and cell length and width of 20 cells per picture were measured using ImageJ (National Institutes of Health $(\mathrm{NIH})$, Bethesda, MD, USA). Cell elongation index was calculated by dividing the length by the width.

Determination of migration and invasion. In all, $1 \times 10^{5}$ cells were seeded onto $8 \mu \mathrm{m}$ transwell migration chambers (Corning Inc., Wiesbaden, Germany), stimulated by adding $2.5 \mu \mathrm{M}$ BV6 both to the lower and the upper chambers to avoid any gradient effect and left to migrate for $24 \mathrm{~h}$. Cells on the upper part of the membrane were scraped using a cotton swab. Migrated cells were fixed in $4 \%$ paraformaldehyde and stained with $0.4 \%$ crystal violet. For quantification, crystal violet staining was re-solubilized in a solution containing $1 \%$ SDS and absorbance was measured at $550 \mathrm{~nm}$ using a microplate reader (TECAN Infinite M200, Crailsheim, Germany).

For determination of invasion, cells were mixed with $1.7 \mathrm{mg} / \mathrm{ml}$ fluorescein (FITC)-conjugated collagen type I (Invitrogen) solution and seeded in a 48-well plate at the density of $1 \times 10^{6} \mathrm{cells} / \mathrm{ml}$. After polymerization of collagen, phenolred-free DMEM medium was added with $2.5 \mu \mathrm{M}$ BV6 or dimethylsulfoxyde (DMSO) for $24 \mathrm{~h}$. As invasive cells degrade the extracellular matrix thereby releasing FITCconjugated collagen into the supernatant, invasion was assessed by measuring absorbance of the supernatant at $520 \mathrm{~nm}$ using a microplate reader (TECAN Infinite M200). Invasion of cells expressing $\mid \kappa B \alpha-S R$ and NIK or TNFR1 knockdown cells was analyzed using transwell migration chambers pre-coated with collagen $(1.4 \mathrm{mg} /$ $\mathrm{ml}$ collagen type I) using the same protocol as described above for the transwell migration assay.

Immunofluorescent staining and confocal microscopy. T98G cells were grown in labtek chamber slides (BD Biosciences, Heidelberg, Germany), fixed with $4 \%$ paraformaldehyde after treatment with BV6, permeabilized with $0.1 \%$ Triton- $100 \mathrm{X}$ for $10 \mathrm{~min}$ and stained overnight at $4{ }^{\circ} \mathrm{C}$ for F-actin with Oregon green 488 phalloidin (Invitrogen). All images were obtained using a Nikon C1si confocal microscope (Nikon, Tokyo, Japan). Images were computer processed in ImageJ and Adobe Photoshop CS3 (Adobe Systems Inc., San Jose, CA, USA)

Western blotting. Western blot analysis was performed as described previously $^{46}$ using the following antibodies: anti-clAP1 (R\&D Systems, Inc., Wiesbaden-Nordenstadt, Germany), anti-clAP2 (Epitomics, Burlingam, CA, USA), anti-XIAP and anti-Smac from BD Biosciences, anti-caspase-3, anti-NIK and antiphospho-p65 from Cell Signaling (Beverly, MA, USA), anti- $\beta$-actin (Sigma), anti- $\alpha$ tubulin (Calbiochem, Darmstadt, Germany), anti-p50, anti-p65, anti-RelB and antiTNFR1 from Santa Cruz Biotechnology (Santa Cruz, CA, USA), anti-p52 (Millipore, Schwalbach, Germany), anti-lamin A/C (Novacastra, Berlin, Germany) and anti-GAPDH (BioTrend, Cologne, Germany). Donkey anti-mouse IgG, donkey anti-rabbit IgG or donkey anti-goat IgG labeled with IRDye infrared dyes were used for fluorescence detection at $700 \mathrm{~nm} 800 \mathrm{~nm}$ (LI-COR Biotechnology, Bad Homburg, Germany). Caspase-3 was immunodetected by enhanced chemoluminescence (Amersham Biosciences, Freiburg, Germany) using an anti-rabbit IgG-HRP as secondary antibody.

Nuclear extractions and EMSA. Nuclear extracts were prepared as previously described. ${ }^{47}$ Shortly, cells were washed, scraped, and collected by centrifugation at 2500 r.p.m for $5 \mathrm{~min}$ at $4{ }^{\circ} \mathrm{C}$. Cells were resuspended in low salt buffer, lysed for $15 \mathrm{~min}$ on ice, followed by addition of a $10 \%$ Igepal CA-630 solution and centrifugation. The pelleted nuclei were resuspended in high salt buffer and nuclear supernatants were obtained by centrifugation. DNA-binding activity of NF- $\kappa$ B was analyzed by EMSA and the following sequence was used as specific oligomer for NF- $\kappa$ B: $5^{\prime}$-AGTTGAGGGGACTTTCCCAGGC-3' (sense). Single-stranded oligonucleotides were labeled with $\gamma$-[32P]-ATP by T4-polynucleotide kinase (MBI Fermentas $17 \mathrm{GmbH}$, St. Leon-Rot, Germany), annealed to the complementary oligomer strand and purified on sephadex columns (Illustra Nick Columns, GE Healthcare, Piscataway, NJ, USA). Binding reactions containing $5 \mu \mathrm{g}$ nuclear extract, $1 \mu \mathrm{g}$ Poly(dl:dC) (Sigma), labeled oligonucleotide (10 000 c.p.m.) and $5 \times$ binding buffer were incubated for $30 \mathrm{~min}$ on ice. Binding complexes were resolved by electrophoresis in non-denaturing $6 \%$ polyacrylamide gels using $0.5 \times$ TBE as running buffer and assessed by autoradiography. For EMSA supershift experiments, binding reactions containing $2.5 \mu \mathrm{g}$ nuclear extract were incubated for $30 \mathrm{~min}$ at room temperature with $4 \mu \mathrm{g}$ of the following antibodies before addition of labeled oligonucleotides: anti-p50 
(sc-1190x), anti-p65 (sc-372X), anti-RelB (sc-226X), anti-c-Rel (sc-70X) (all from Santa Cruz) or anti-p52 (Millipore).

Luciferase assay. The Dual-Luciferase Reporter Assay System (Promega, Mannheim, Germany) was used to determine firefly and Renilla luciferase activities according to the manufacturer's instructions. Cells were seeded in 12-well plates and transfected both with $3 \times \kappa \mathrm{B}$-firefly luciferase vector containing $3 \times \kappa \mathrm{B}$ consensus motif ( $5^{\prime}$-CCCTGAAAGG-3') and Renilla luciferase vector under the control of the ubiquitin promoter using Fugene 6 Transfection Reagent (Roche Diagnostics). The day after transfection, cells were stimulated with $2.5 \mu \mathrm{M}$ BV6 or DMSO. After $24 \mathrm{~h}$ of stimulation, cells were lysed and luciferase activities were measured with a microplate reader (TECAN Infinite M200). Firefly luciferase values were normalized to Renilla luciferase values.

Quantitative RT-PCR. Total RNA was extracted using peqGOLD Total RNA kit from Peqlab Biotechnologie GmbH (Erlangen, Germany) according to the manufacturer's instructions. In all, $2 \mu \mathrm{g}$ of total RNA were used to synthetize the corresponding cDNA using RevertAid H Minus First Strand cDNA Synthesis Kit (MBI Fermentas $\mathrm{GmbH}$ ). To quantify gene expression levels, SYBR-Green based qRT-PCR was performed using the $7900 \mathrm{HT}$ fast real-time PCR system from Applied Biosystems (Darmstadt, Germany). Data were normalized on 18S-rRNA expression as reference gene. Primers are listed in Supplementary Table 1. Melting curves were plotted to verify the specificity of the amplified products. All determinations were performed in triplicate. The relative expression of the target gene transcript and reference gene transcript was calculated as $\Delta \Delta \mathrm{C}_{\mathrm{t}}$. Two independent experiments were done for each gene.

CAM assay and primary GBM cultures. CAM assay was done as described previously. ${ }^{28}$ Briefly, $1 \times 10^{6}$ T98G cells were resuspended in $10 \mu \mathrm{l}$ serum-free medium and $10 \mu \mathrm{l}$ Matrigel matrix (BD Biosciences) after treatment with or without $2.5 \mu \mathrm{M}$ BV6 for $24 \mathrm{~h}$ and implanted on the CAM of fertilized chicken eggs on day 8 of incubation. Four days after inoculation, tumors were excised with the surrounding CAM, fixed in $4 \%$ paraformaldehyde, embedded in paraffin, cut in $5 \mu \mathrm{m}$ sections and stained with $1: 1$ hematoxylin and $0.5 \%$ eosin solution for histological analysis. Images were digitally recorded with an SZ61 microscope (Olympus, Center Valley, PA, USA) and tumor area was analyzed using ImageJ digital imaging software (NIH). Primary GBM cultures (GBM1, GBM2) were established from surgical specimens obtained from two patients with grade 4 glioma and were characterized and cultured as described previously. ${ }^{48}$ The study was approved by the ethics committee, Medical Faculty, University of Frankfurt.

Statistical Analysis. Statistical significance was assessed by two-sided Student's $t$-test using Microsoft Excel (Microsoft Deutschland GmbH, Unterschleißheim, Germany).

\section{Conflict of Interest}

The authors declare no conflict of interest.

Acknowledgements. We thank D Vucic (Genentech, South San Francisco, CA, USA) for providing BV6, D Brücher for expert technical assistance and C Hugenberg for expert secretarial assistance. This work has been partially supported by grants from the Deutsche Forschungsgemeinschaft, European Community (ApopTrain, APO-SYS) and IAP6/18 (to SF).

1. Fulda S, Vucic D. Targeting IAP proteins for therapeutic intervention in cancer. Nat Rev Drug Discov 2012; 11: 109-124.

2. Eckelman BP, Salvesen GS, Scott FL. Human inhibitor of apoptosis proteins: why XIAP is the black sheep of the family. EMBO Rep 2006; 7: 988-994.

3. Kim J, Ahn S, Ko YG, Boo YC, Chi SG, Ni CW et al. X-linked inhibitor of apoptosis protein controls alpha5-integrin-mediated cell adhesion and migration. Am J Physiol Heart Circulatory Physiol 2010; 299: H300-H309.

4. Liu J, Zhang D, Luo W, Yu Y, Yu J, Li J et al. X-linked inhibitor of apoptosis protein (XIAP) mediates cancer cell motility via Rho GDP dissociation inhibitor (RhoGDI)-dependent regulation of the cytoskeleton. J Biol Chem 2011; 286: 15630-15640.

5. Mehrotra S, Languino LR, Raskett CM, Mercurio AM, Dohi T, Altieri DC. IAP regulation of metastasis. Cancer Cell 2010; 17: 53-64.
6. Lopez J, John SW, Tenev T, Rautureau GJ, Hinds MG, Francalanci F et al. CARD-mediated autoinhibition of clAP1's E3 ligase activity suppresses cell proliferation and migration. Mol Cell 2011; 42: 569-583.

7. Dogan T, Harms GS, Hekman M, Karreman C, Oberoi TK, Alnemri ES et al. X-linked and cellular IAPs modulate the stability of C-RAF kinase and cell motility. Nat Cell Biol 2008; 10: 1447-1455.

8. Oberoi TK, Dogan T, Hocking JC, Scholz RP, Mooz J, Anderson CL et al. IAPs regulate the plasticity of cell migration by directly targeting Rac1 for degradation. EMBO J 2012; 31: 14-28.

9. Oeckinghaus A, Hayden MS, Ghosh S. Crosstalk in NF-kappaB signaling pathways. Nat Immunol 2011; 12: 695-708.

10. Varfolomeev E, Goncharov T, Fedorova AV, Dynek JN, Zobel K, Deshayes K et al. c-IAP1 and C-IAP2 are critical mediators of tumor necrosis factor alpha (TNFalpha)-induced NF-kappaB activation. J Biol Chem 2008; 283: 24295-24299.

11. Bertrand MJ, Milutinovic S, Dickson KM, Ho WC, Boudreault A, Durkin J et al. clAP1 and CIAP2 facilitate cancer cell survival by functioning as E3 ligases that promote RIP1 ubiquitination. Mol Cell 2008; 30: 689-700.

12. Vallabhapurapu S, Matsuzawa A, Zhang W, Tseng PH, Keats JJ, Wang $\mathrm{H}$ et al. Nonredundant and complementary functions of TRAF2 and TRAF3 in a ubiquitination cascade that activates NIK-dependent alternative NF-kappaB signaling. Nat Immunol 2008; 9: 1364-1370.

13. Zarnegar BJ, Wang Y, Mahoney DJ, Dempsey PW, Cheung HH, He J et al. Noncanonical NF-kappaB activation requires coordinated assembly of a regulatory complex of the adaptors CIAP1, cIAP2, TRAF2 and TRAF3 and the kinase NIK. Nat Immunol 2008; 9: $1371-1378$.

14. Varfolomeev E, Blankenship JW, Wayson SM, Fedorova AV, Kayagaki N, Garg P et al. IAP antagonists induce autoubiquitination of c-IAPs, NF-kappaB activation, and TNFalpha-dependent apoptosis. Cell 2007; 131: 669-681.

15. Vince JE, Wong WW, Khan N, Feltham R, Chau D, Ahmed AU et al. IAP antagonists target cIAP1 to induce TNFalpha-dependent apoptosis. Cell 2007; 131: 682-693.

16. Wu Y, Zhou BP. TNF-alpha/NF-kappaB/Snail pathway in cancer cell migration and invasion. Br J Cancer 2010; 102: 639-644.

17. Giese A, Bjerkvig R, Berens ME, Westphal M. Cost of migration: invasion of malignant gliomas and implications for treatment. J Clin Oncol 2003; 21: 1624-1636.

18. Claes A, Idema AJ, Wesseling P. Diffuse glioma growth: a guerilla war. Acta Neuropathol 2007; 114: 443-458.

19. Raychaudhuri B, Han Y, Lu T, Vogelbaum MA. Aberrant constitutive activation of nuclear factor kappaB in glioblastoma multiforme drives invasive phenotype. J Neurooncol 2007; 85: 39-47.

20. Tsunoda K, Kitange G, Anda T, Shabani HK, Kaminogo M, Shibata S et al. Expression of the constitutively activated RelA/NF-kappaB in human astrocytic tumors and the in vitro implication in the regulation of urokinase-type plasminogen activator, migration, and invasion. Brain Tumor Pathol 2005; 22: 79-87.

21. Chakravarti A, Noll E, Black PM, Finkelstein DF, Finkelstein DM, Dyson NJ et al. Quantitatively determined survivin expression levels are of prognostic value in human gliomas. J Clin Oncol 2002; 20: 1063-1068.

22. Shi YH, Ding WX, Zhou J, He JY, Xu Y, Gambotto AA et al. Expression of X-linked inhibitorof-apoptosis protein in hepatocellular carcinoma promotes metastasis and tumor recurrence. Hepatology 2008; 48: 497-507.

23. Weber RG, Sommer C, Albert FK, Kiessling M, Cremer T. Clinically distinct subgroups of glioblastoma multiforme studied by comparative genomic hybridization. Lab Invest 1996; 74: 108-119.

24. Wagenknecht B, Glaser T, Naumann U, Kugler S, Isenmann S, Bahr M et al. Expression and biological activity of X-linked inhibitor of apoptosis (XIAP) in human malignant glioma. Cell Death Differ 1999; 6: 370-376.

25. Verhagen AM, Ekert PG, Pakusch M, Silke J, Connolly LM, Reid GE et al. Identification of DIABLO, a mammalian protein that promotes apoptosis by binding to and antagonizing IAP proteins. Cell 2000; 102: 43-53.

26. Du C, Fang M, Li Y, Li L, Wang X. Smac, a mitochondrial protein that promotes cytochrome c-dependent caspase activation by eliminating IAP inhibition. Cell 2000; 102: 33-42.

27. Gaither A, Porter D, Yao Y, Borawski J, Yang G, Donovan J et al. A Smac mimetic rescue screen reveals roles for inhibitor of apoptosis proteins in tumor necrosis factor-alpha signaling. Cancer Res 2007; 67: 11493-11498.

28. Hacker S, Dittrich A, Mohr A, Schweitzer T, Rutkowski S, Krauss J et al. Histone deacetylase inhibitors cooperate with IFN-gamma to restore caspase-8 expression and overcome TRAIL resistance in cancers with silencing of caspase-8. Oncogene 2009; 28: 3097-3110.

29. Unterkircher T, Cristofanon S, Vellanki SH, Nonnenmacher L, Karpel-Massler G, Wirtz CR et al. Bortezomib primes glioblastoma, including glioblastoma stem cells, for TRAIL by increasing tBid stability and mitochondrial apoptosis. Clin Cancer Res 2011; 17: 4019-4030.

30. Liptay S, Schmid RM, Nabel EG, Nabel GJ. Transcriptional regulation of NF-kappa B2: evidence for kappa B-mediated positive and negative autoregulation. Mol Cell Biol 1994; 14: 7695-7703.

31. Bren GD, Solan NJ, Miyoshi H, Pennington KN, Pobst LJ, Paya CV. Transcription of the RelB gene is regulated by NF-kappaB. Oncogene 2001; 20: 7722-7733. 
32. Cheng SM, Xing B, Li JC, Cheung BK, Lau AS. Interferon-gamma regulation of TNFalphainduced matrix metalloproteinase 3 expression and migration of human glioma T98G cells. Int J Cancer 2007; 121: 1190-1196.

33. Wagner L, Marschall V, Karl S, Cristofanon S, Zobel K, Deshayes K et al. Smac mimetic sensitizes glioblastoma cells to Temozolomide-induced apoptosis in a RIP1- and NF-kappaB-dependent manner. Oncogene 2013; 32: 988-997.

34. Berger R, Jennewein $C$, Marschall V, Karl S, Cristofanon S, Wagner $L$ et al. NF-\{kappa\}B is required for Smac mimetic-mediated sensitization of glioblastoma cells for \{gamma\}-irradiation-induced apoptosis. Mol Cancer Ther 2011; 10 : 1867-1875.

35. Vellanki SH, Grabrucker A, Liebau S, Proepper C, Eramo A, Braun V et al. Small-molecule XIAP inhibitors enhance gamma-irradiation-induced apoptosis in glioblastoma. Neoplasia 2009; 11: 743-752.

36. Fulda S, Wick W, Weller M, Debatin KM. Smac agonists sensitize for Apo2L/TRAIL- or anticancer drug-induced apoptosis and induce regression of malignant glioma in vivo. Nat Med 2002; 8: 808-815.

37. Woronicz JD, Gao X, Cao Z, Rothe M, Goeddel DV. IkappaB kinase-beta: NF-kappaB activation and complex formation with IkappaB kinase-alpha and NIK. Science 1997; 278: 866-869.

38. Ling L, Cao Z, Goeddel DV. NF-kappaB-inducing kinase activates IKK-alpha by phosphorylation of Ser-176. Proc Natl Acad Sci USA 1998; 95: 3792-3797.

39. Kew RR, Penzo M, Habiel DM, Marcu KB. The IKKalpha-dependent NF-kappaB p52/RelB noncanonical pathway is essential to sustain a CXCL12 autocrine loop in cells migrating in response to HMGB1. J Immunol 2012; 188: 2380-2386.

40. Penzo M, Molteni R, Suda T, Samaniego S, Raucci A, Habiel DM et al. Inhibitor of NFkappa B kinases alpha and beta are both essential for high mobility group box 1-mediated chemotaxis [corrected]. J Immunol 2010; 184: 4497-4509.

41. Rangaswami H, Bulbule A, Kundu GC. Nuclear factor inducing kinase: a key regulator in osteopontin- induced MAPK/lkappaB kinase dependent NF-kappaB-mediated promatrix metalloproteinase-9 activation. Glycoconjugate J 2006; 23: 221-232.
42. Kim JY, Morgan M, Kim DG, Lee JY, Bai L, Lin Y et al. TNFalpha induced noncanonical NF-kappaB activation is attenuated by RIP1 through stabilization of TRAF2. J Cell Sci 2011; 124: 647-656.

43. Gentle IE, Wong WW, Evans JM, Bankovacki A, Cook WD, Khan NR et al. In TNF-stimulated cells, RIPK1 promotes cell survival by stabilizing TRAF2 and cIAP1, which limits induction of non-canonical NF-kappaB and activation of caspase-8. J Biol Chem 2011; 286: 13282-13291.

44. Karl S, Pritschow Y, Volcic M, Hacker S, Baumann B, Wiesmuller L et al. Identification of a novel pro-apopotic function of NF-kappaB in the DNA damage response. J Cell Mol Med 2009; 13: 4239-4256.

45. Gonzalez P, Mader I, Tchoghandjian A, Enzenmuller S, Cristofanon S, Basit F et al. Impairment of lysosomal integrity by B10, a glycosylated derivative of betulinic acid, leads to lysosomal cell death and converts autophagy into a detrimental process. Cell Death Differ 2012; 19: 1337-1346.

46. Vogler M, Durr K, Jovanovic M, Debatin KM, Fulda S. Regulation of TRAIL-induced apoptosis by XIAP in pancreatic carcinoma cells. Oncogene 2007; 26: 248-257.

47. Kasperczyk H, La Ferla-Bruhl K, Westhoff MA, Behrend L, Zwacka RM, Debatin K-M et al. Betulinic acid as new activator of NF-kappaB: molecular mechanisms and implications for cancer therapy. Oncogene 2005; 24: 6945-6956.

48. Fulda S, Friesen C, Los M, Scaffidi C, Mier W, Benedict M et al. Betulinic acid triggers CD95 (APO-1/Fas)- and p53-independent apoptosis via activation of caspases in neuroectodermal tumors. Cancer Res 1997; 57: 4956-4964.

(c) (1) $\Theta($ Cell Death and Disease is an open-access journal published by Nature Publishing Group. This work is licensed under a Creative Commons Attribution-NonCommercialNoDerivs 3.0 Unported License. To view a copy of this license, visit http://creativecommons.org/licenses/by-nc-nd/3.0/

Supplementary Information accompanies this paper on Cell Death and Disease website (http://www.nature.com/cddis) 